Supplement of Atmos. Chem. Phys., 21, 6509-6539, 2021

https://doi.org/10.5194/acp-21-6509-2021-supplement

(C) Author(s) 2021. CC BY 4.0 License.

(c) (1)

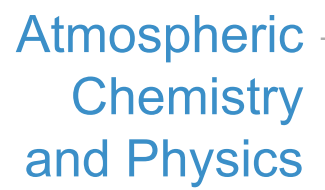

Supplement of

\title{
Chemical composition and source attribution of sub-micrometre aerosol particles in the summertime Arctic lower troposphere
}

Franziska Köllner et al.

Correspondence to: Franziska Köllner (f.koellner@mpic.de)

The copyright of individual parts of the supplement might differ from the article licence. 


\section{S1 Scaling procedure and hit rate variability for the NETCARE 2014 ALABAMA data}

The conversion of unscaled ALABAMA measurements into quantitative particle number concentrations is provided as an example in Fig. S1.

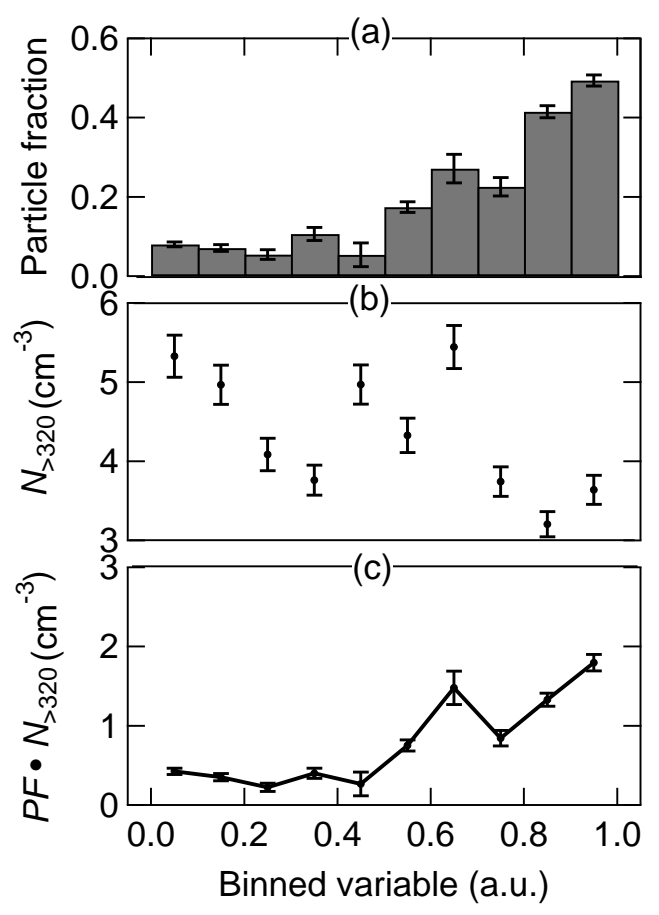

Figure S1. Example for the three-step scaling procedure. (a) The ALABAMA number fraction of the specific particle type ( $P F$ ), (b) the averaged UHSAS number concentration in a size range between $320 \mathrm{~nm}$ and $870 \mathrm{~nm}\left(N_{>320}\right)$, (c) and the scaled ALABAMA number concentration $\left(P F \cdot N_{>320}\right)$ are compared with variables that are simultaneously measured. In this study, we used the following variables: FLEXPART PES fractions, altitude, $\mathrm{H} / \mathrm{C}$ ratio, $\mathrm{O} / \mathrm{C}$ ratio, and $\mathrm{CO}$ mixing ratio.

The following approach estimates the NETCARE 2014 hit rate variability that is controlled by several instrumental issues. The instrument hit rate is defined as the number of particles that are successfully ionized by the ablation laser and that create a mass spectrum relative to the number of laser shots (Clemen et al., 2020). The triggered shot requires that the particle velocity was prior successfully determined and that the laser was ready to shoot (Brands et al., 2011). The maximum shot repetition rate of the Nd:YAG laser was set to $12 \mathrm{~Hz}$. Figure S1 presents the distribution of the averaged hit rate measured during the Arctic field experiment outside clouds. By assuming that the measured distribution cannot solely be explained by binomial distributed numbers, it needs to be described by a combination of both binomial distributed numbers and the variability caused by instrumental issues. Combined with the Gaussian propagation of uncertainties, the relative standard deviation of the measured hit rate distribution $\left(\sigma_{\text {measured }}\right)$ can thus be estimated as follows:

$\sigma_{\text {measured }}^{2}=\sigma_{\text {binomial }}^{2}+\sigma_{\text {others }}^{2}$,

with $\sigma_{\text {measured }}=0.06$, the relative standard deviation related to instrumental issues $\left(\sigma_{\text {others }}\right)$, and the relative standard deviation of the Binomial probability distribution $\left(\sigma_{\text {binomial }}\right)$, which is calculated as follows:

$\sigma_{\text {binomial }}=\frac{\sqrt{N \cdot p \cdot q}}{N}$ 


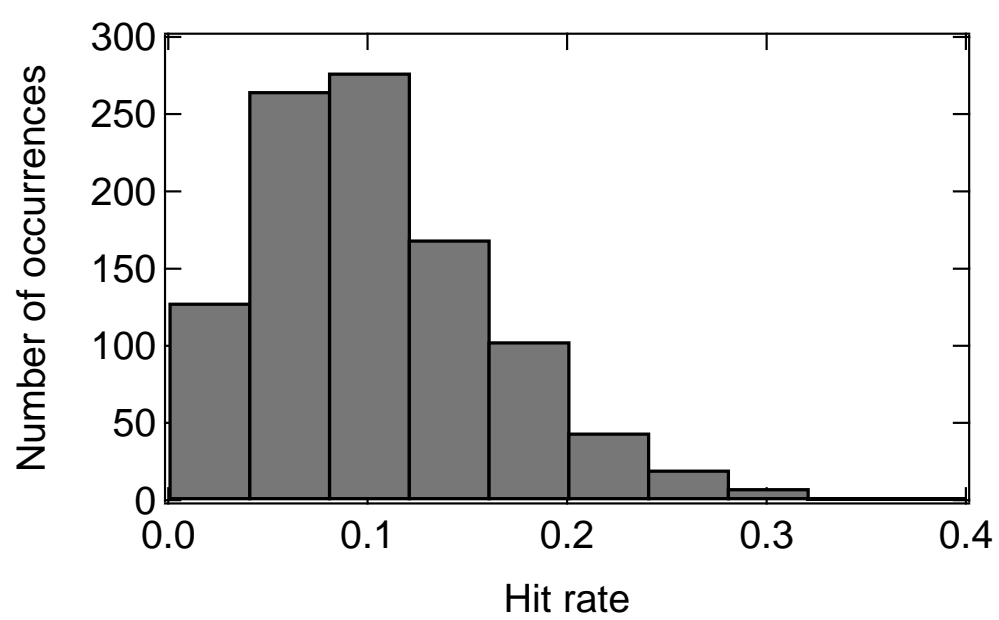

Figure S2. Histogram of hit rate values with each value includes $N=100$ trials (here, laser shots), measured during the Arctic field experiment (NETCARE 2014) outside clouds. The averaged hit rate value is $0.1(p=0.1)$.

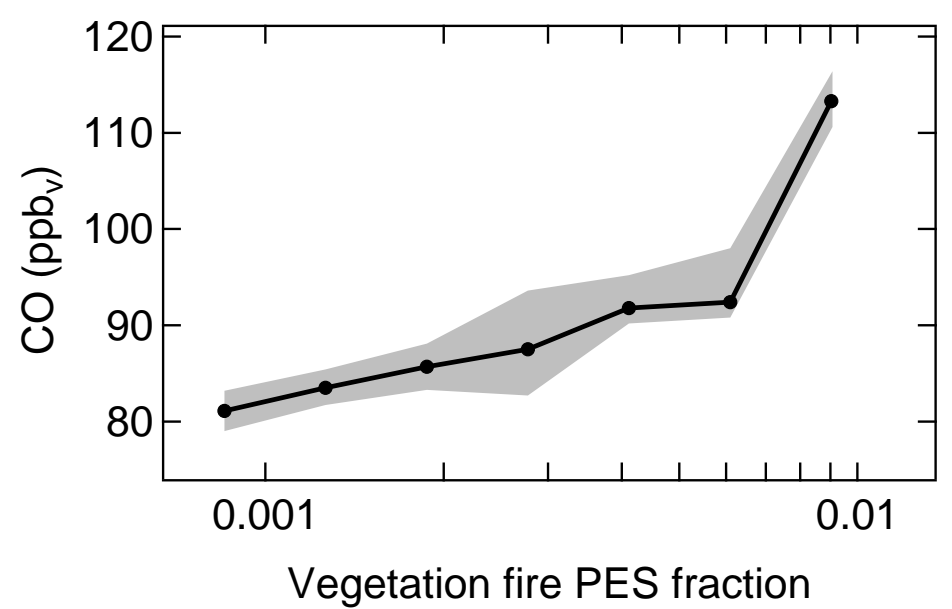

Figure S3. CO mixing ratios as a function of FLEXPART predicted PES fraction over vegetation fires during the southern air mass period. The graph presents the median (solid line with marker) and interquartile ranges (shaded area) of the CO mixing ratios.

with trials $(N)$ is 100 , probability of success $(p)$ is 0.1 , and probability of failure $(q)$ is 0.9 . The resulting $\sigma_{\text {binomial }}$ is 0.03 . Based on $\sigma_{\text {binomial }}$ and Eq. 1 , the $\sigma_{\text {others }}$ is 0.05 . Together, since the averaged ALABAMA hit rate of 0.1 can vary by 0.05 due to instrumental issues, it is assumed for the analyses in Sections 3.2 and 3.3 that the particle fraction needs to vary by more than a factor of 2 to be significant. 


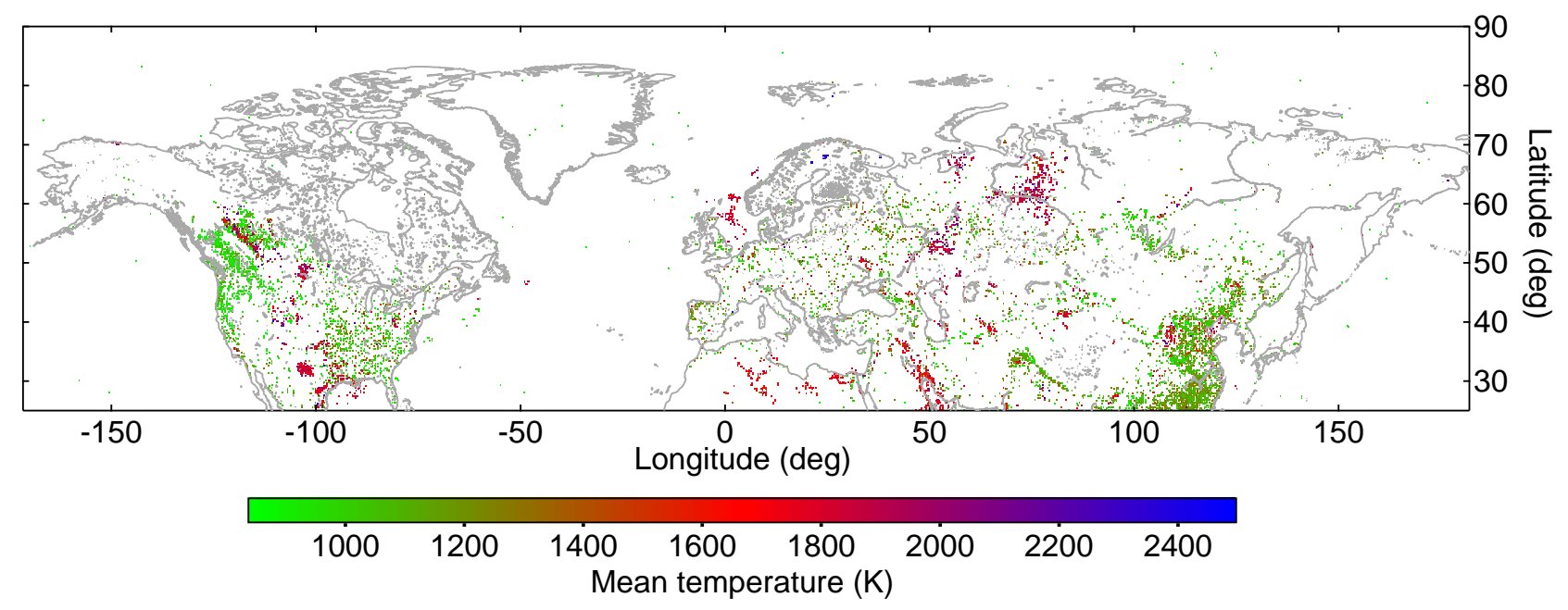

Figure S4. Map showing the mean infrared emission temperatures of industrial heat sources for November 2013 until January 2014.

\section{S2 Source sectors}

\section{S2.1 Vegetation fires}

The Visible Infrared Imaging Radiometer Suite (VIIRS) onboard the Suomi National Polar-Orbiting Partnership spacecraft can detect sub-pixel thermal anomalies by signals in mid- and thermal infrared spectral range (Schroeder et al., 2014; Schroeder and Giglio, 2018). Thermal anomalies typically include both active vegetation fires and industrial heat sources by fossil-fuel combustion etc. Data of the so-called near real-time VIIRS 375 m Active Fire product were downloaded online for 19 June until 21 July 2014 (NASA, 2018) and projected on the gridded maps by adding up observations in each grid cell. Thermal anomalies were identified by one or more observations per grid cell within the respective time.

The presence of vegetation fires can be distinguished from other thermal anomalies by the following approach. Anthropogenic heat sources, such as industry, flaring, and densely populated regions, are separately mapped (see following sections) and subsequently excluded from the thermal anomaly map. Residual heat sources in Fig. 3a thus present vegetation fires, accumulated for 19 June until 21 July 2014. This approach looks reasonable in comparison with Arndt et al. (2015), at least for boreal fires in northern Canada and Siberia. North American and north Asian biomass burning budgets were anomalously high in 2014 compared to 2001 - 2013 (Fig. 2.57 and Table 2.8 in Arndt et al., 2015). Particularly in summer 2014, large fires in the Great Slave Lake region and Siberia were evident (Fig. 2.40 in Arndt et al., 2015), confirming results in Fig. 3a. Consistent with this, Fig. S2 shows a positive correlation between CO mixing ratios and residence time spent over vegetation fires. However, the main weakness of this approach is given by temporal variabilities of the data sets.

Vegetation fire injection heights are highly variable owing to a combination of fire type, fuel consumption, and prevailing meteorological conditions (e.g., Lavoué et al., 2000; Andreae and Merlet, 2001; Leung et al., 2007; Kondo et al., 2011; Val Martin et al., 2018). Several studies show injection heights for boreal fires in North America and Siberia primary between $1 \mathrm{~km}$ and 5 km (e.g., Lavoué et al., 2000; Stohl, 2006; Turquety et al., 2007; Leung et al., 2007; Val Martin et al., 2018). In view of having no better information, the footprint layer for vegetation fires is here defined between $1 \mathrm{~km}$ and $5 \mathrm{~km}$.

\section{S2.2 Industrial sources and flaring}

The Nightfire product from VIIRS offers quantitative estimates of infrared source emission temperatures by taking advantage of absent solar reflectance in short-wave infrared spectral range during night (Elvidge et al., 2013, 2016). Emission temperatures typically exhibit bimodal distributions by a combination of gas flares dominating the upper mode (peaking in the $1600-2000 \mathrm{~K}$ 
range) and other industrial heat sources as well as vegetation fires dominating the lower mode (peaking in the 800 - $1200 \mathrm{~K}$ range; Elvidge et al., 2016; Liu et al., 2018). Thus, temperature distributions of vegetation fires and industrial sources can overlap, depending on the industry sector and the vegetation type. However, vegetation fires at mid- to northern latitudes exhibit a clear seasonality with minimum occurrence between November and January (e.g., Giglio et al., 2013). Consequently, this analysis took advantage of both emission temperatures and seasonality to differentiate between the presence of industrial hot spots and vegetation fires (Elvidge et al., 2013; Liu et al., 2018). VIIRS Nightfire data were thus downloaded for November 2013 until January 2014 and for latitudes north of $25^{\circ} \mathrm{N}$ (NOAA, 2018a). Data points were projected on the gridded map by averaging temperatures in each grid cell (Fig. S2). Industrial hot spots were identified by both pixel mean temperature larger than $840 \mathrm{~K}^{1}$ as well as one or more observations per grid cell within the respective time, owing to source persistence (Fig. 3b). Gas flares can be clearly detected by VIIRS Nightfire emission temperatures between $1600 \mathrm{~K}$ and $2000 \mathrm{~K}$ (Fig. S2) independent on season (Elvidge et al., 2016). Based on this temperature definition, VIIRS Nightfire provide the so-called Flares only product (NOAA, 2018b). Data between 30 March and 13 May 2014², were projected on the gridded map by adding up observations in each grid cell. Flares were identified by more than one observation per grid cell within the respective time, owing to source persistence (Fig. 3c).

Both approaches look reasonable by comparing Figs. 3b and c with Fig. 8 in Elvidge et al. (2016) and Fig. 8 in Liu et al. (2018). Oil/gas- and coal-related plants in northwestern Siberia (near Norilsk and Novy Urengoy), northern Europe (North Sea, Norwegian Sea, and Nenets region) and Alaska (Prudhoe Bay) can be clearly identified (Figs. 3b and c). However, uncertainties remain by non-continuously operating industrial sources.

\section{S2.3 Population}

Populated areas provide anthropogenic emissions from residential heating, transportation, cooking etc. The criteria for the grid cell to be classified as populated is given by more than 1000 people live in a $0.25^{\circ} \times 0.25^{\circ}$ area. Geolocational data on population are provided online (MaxMind, 2018). Densely populated regions in central Europe and coastal North American can be clearly identified, whereas Northern Canada, Alaska, and Siberia present sparsely populated regions (Fig. 3d).

\section{S2.4 Arctic natural marine sources}

Sea ice coverage in July 2014 is assessed to obtain areas of open water in the Arctic. The Special Sensor Microwave Imager/Sounder (SSMIS) onboard the Defense Meteorological Satellite Program (DMSP) provides data on sea ice coverage, based on brightness temperature (Cavalieri et al., 1996, updated yearly). Data represent the fractional amount of sea ice covering a $25 \times 25 \mathrm{~km}$ grid cell in a polar stereographic projection. Polar stereographic coordinates were converted to geodetic latitude and longitude for polar regions (Snyder, 1982) ${ }^{3}$. The obtained data grid was synchronized with the gridded map by averaging concentrations in each grid cell. Arctic open water is defined by both sea ice concentrations less than $30 \%$ and latitudes north of $73.5^{\circ} \mathrm{N}$ (Fig. 3e).

\section{S3 Representativeness of the July 2014 measurement periods}

It is of relevance to assess the representativeness of both NETCARE 2014 periods with respect to climatological conditions, i.e. mean conditions between 1981 - 2010. Climatic anomalies were obtained by using re-analysis data prepared by NCEP/NCAR (Kalnay et al., 1996). Images in Fig. S3 were provided by the NOAA/ESRL Physical Sciences Division, Boulder Colorado, from their web site at http://www.esrl.noaa.gov/psd/data/composites/day/ (Kalnay et al., 1996).

The synoptic situation with the high pressure influence during the Arctic air mass period was generally consistent with the climatology. First, $850 \mathrm{hPa}$ geopotential heights were within $+20 \mathrm{~m}$ of the climatology in the measurement region (Fig. S3a). Second, air temperatures at $850 \mathrm{hPa}$ were maximum $1 \mathrm{~K}$ lower than normal (Fig. S3c). Third, the precipitation anomaly was negligible small (Fig. S3e). Finally, local meteorological conditions, such as the shallow stable stratified BL and low wind

\footnotetext{
$1840 \mathrm{~K}$ presents the lowest mean temperature for industrial sites, indicative for nonmetal-mineral producing plants (Liu et al., 2018).

${ }^{2}$ Data earlier in 2014 are not available and high latitude data later than May are not valuable due to $24 \mathrm{~h}$ solar irradiance.

${ }^{3}$ Source code was taken from ftp://sidads.colorado.edu/pub/DATASETS/seaice/polar-stereo/tools/mapxy.for.
} 
(a)

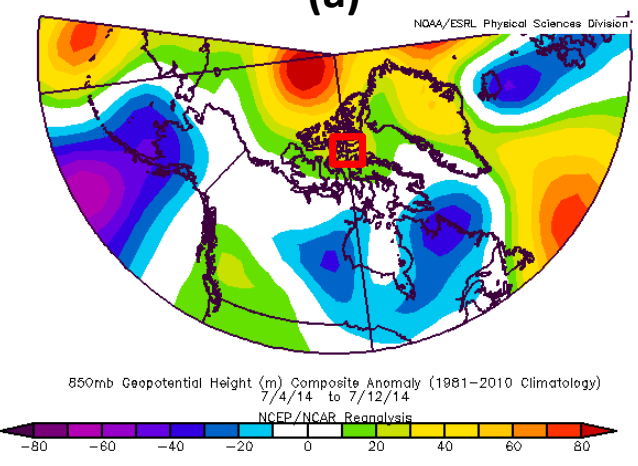

(c)

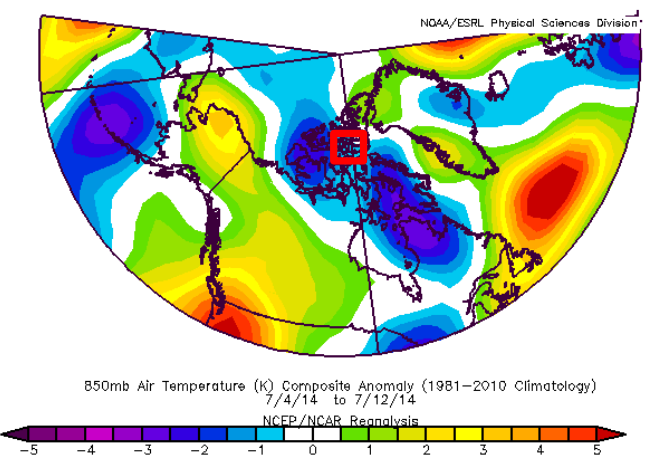

(e)

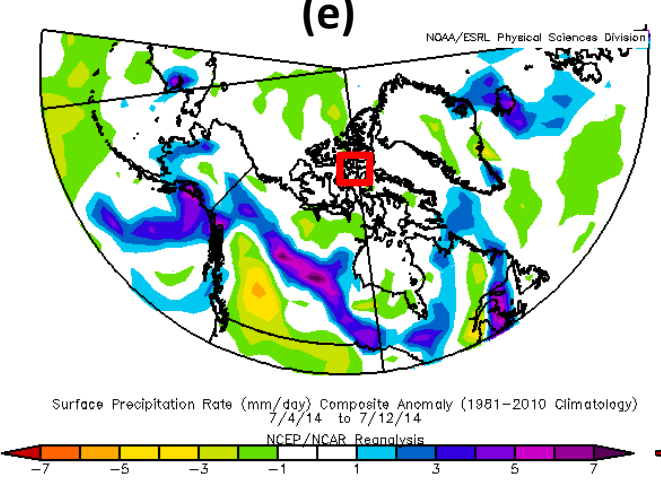

(b)

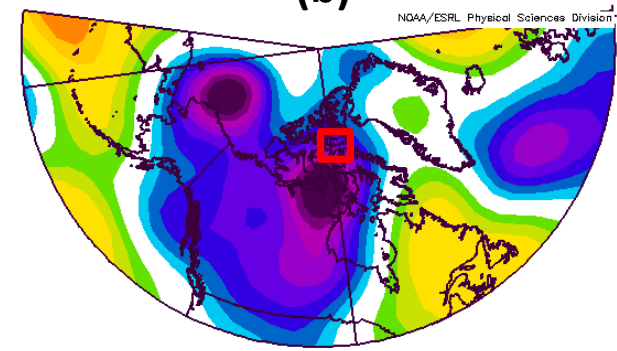

850mb Geopotentiol Height $\{m)$ Composite Anomaly $(1881-2010$ Climatology)

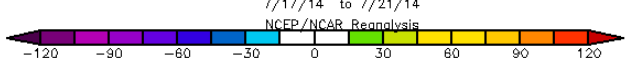

(d)

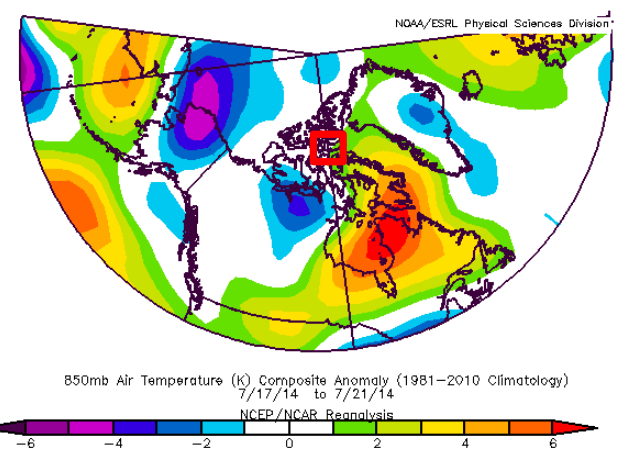

(f)

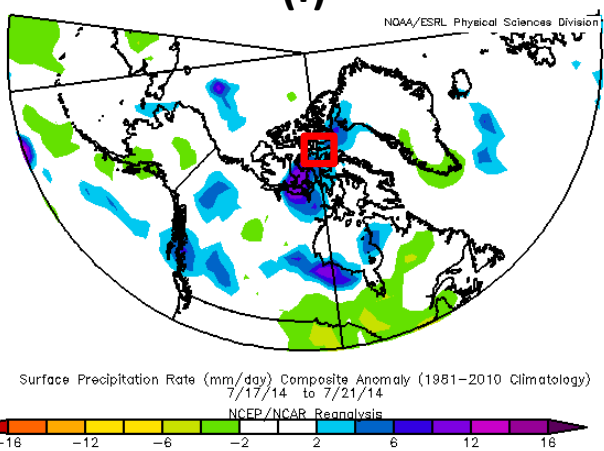

Figure S5. Anomaly from climatological mean (1981 - 2010) of $850 \mathrm{hPa}$ geopotential height (a-b), $850 \mathrm{hPa}$ air temperature (c-d), and $850 \mathrm{hPa}$ precipitation rate (e-f) during the Arctic air mass period (left panel) and the southern air mass period (right panel). The measurement region is marked with a red box. 


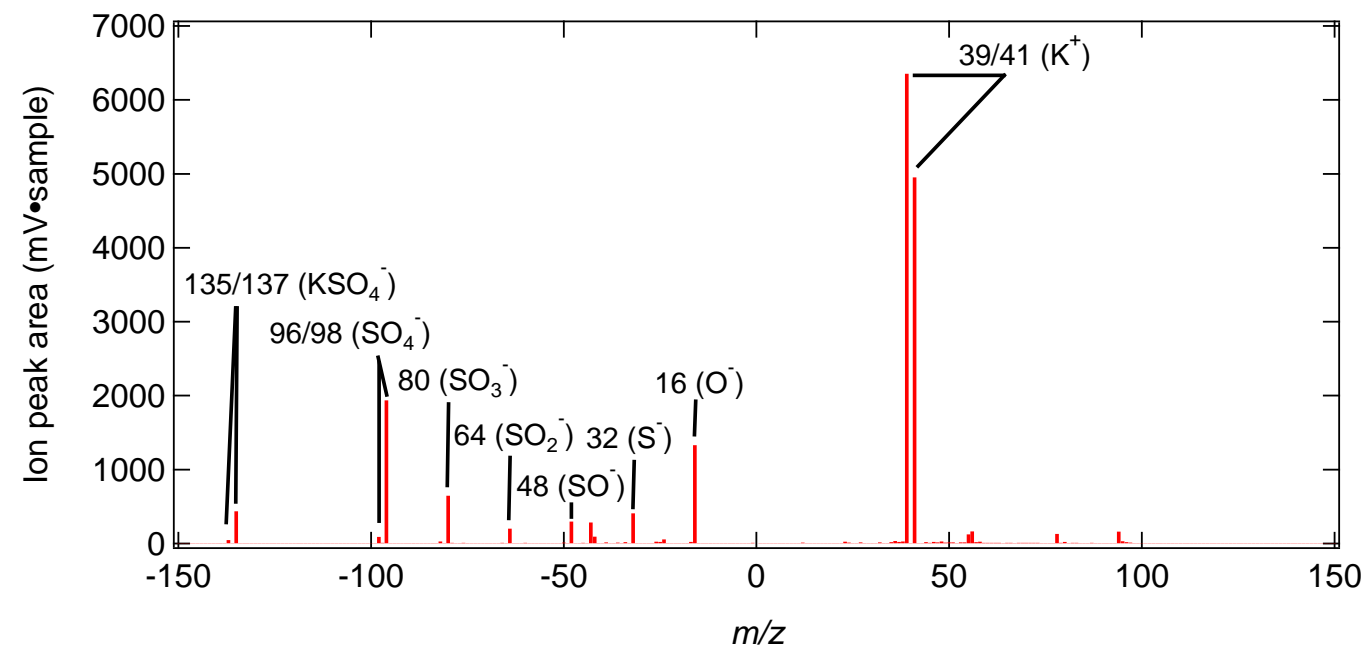

Figure S6. Potassium sulfate $\left(\mathrm{KSO}_{4}\right)$ mean bipolar spectrum of 69 single particle spectra analyzed by the ALABAMA. The isotopic ratio of potassium at $m / z+41$ and $m / z+39$ is too high, likely caused by saturation effects of the MCP.

speeds (see Sect. 3.2.1), represented typical features in the summertime Arctic atmosphere (e.g., Fuelberg et al., 2010; Tjernström et al., 2012).

In contrast to this, the southern air mass period with influences of the low-pressure system centered south of Resolute Bay were significantly anomalous compared to climatological mean. Geopotential height at $850 \mathrm{hPa}$ shows a climatological departure down to $-120 \mathrm{~m}$ close to the center of the low-pressure system (Fig. S3b). Further, warmer air than normal was advected into and more precipitation than normal fell in the measurement region (Figs. S3d and f). Air temperatures at $850 \mathrm{hPa}$ deviated up to $+6 \mathrm{~K}$ from the climatology in the region north-east of the Hudson Bay (Fig. S3d). Additionally, the vegetation fire activity in North America was anomalously high in summer 2014 compared to 2001 - 2013 (Arndt et al., 2015). Together, influences of vegetation fires on Arctic atmospheric composition were larger than on climatological average caused by a combination of anomalous meteorological conditions and intensive fires in northern Canada.

\section{S4 Levoglucosan and Potassium Sulfate}

Levoglucosan (or 1,6-anhydro-beta-glucopyranose; $\mathrm{C}_{6} \mathrm{H}_{10} \mathrm{O}_{5}$ ) is a key organic tracer for vegetation fires (Simoneit et al., 1999). However, there is no consensus in SPMS literature about ion markers of levoglucosan. The averaged laboratory mass spectrum by Silva et al. (1999) shows ion peaks at $\mathrm{m} / \mathrm{z}-45,-59$ and -71 , while others also used $\mathrm{m} / \mathrm{z}-73$ to identify levoglucosan in ambient mass spectra (Moffet et al., 2008; Corbin et al., 2012). Consequently, ALABAMA laboratory measurements were conducted to identify mass spectra characteristics of levoglucosan.

Levoglucosan is poorly absorbing at $266 \mathrm{~nm}$ laser wavelength as found in this laboratory study. Therefore, the better absorbing material $\mathrm{KSO}_{4}$ was mixed with levoglucosan. Both substances were suspended in purified water and nebulized with an aerosol generation system. Diffusion dryers filled with silica gel removed water from the particles and the resulting particles were introduced into the ALABAMA. Analogous to levoglucosan mixed with $\mathrm{KSO}_{4}, \mathrm{KSO}_{4}$ was separately analyzed to differentiate ion peaks originating from levoglucosan and $\mathrm{KSO}_{4}$.

The mean mass spectrum of $\mathrm{KSO}_{4}$ is characterized by molecular ion peaks at m/z-135/137 (Fig. S4). It further shows potassium peaks at $\mathrm{m} / \mathrm{z}+39 / 41$ as well as several fragments that contain sulfur and/or oxygen $(\mathrm{m} / \mathrm{z}-96 / 98,-80,-64,-48,-21$, and -16$)$. In parallel, the mean mass spectrum of levoglucosan is obtained by subtracting the mean spectrum of $\mathrm{KSO}_{4}$ from levoglucosan mixed with $\mathrm{KSO}_{4}$ (Fig. S4). As a result, levoglucosan is characterized by fragments at $\mathrm{m} / \mathrm{z}-71,-59,-45$, confirming laboratory 
measurements by Silva et al. (1999). Additional fragments at m/z-58,-41, and -25 have been also reported by Silva et al. (1999), albeit not dominant in their study. However, these mass spectral characteristics are not unambiguous owing to isobaric interferences with fragments of other oxygen-containing organic compounds (Table S1). It is thus difficult to clearly identify levoglucosan in ambient particle mass spectra.

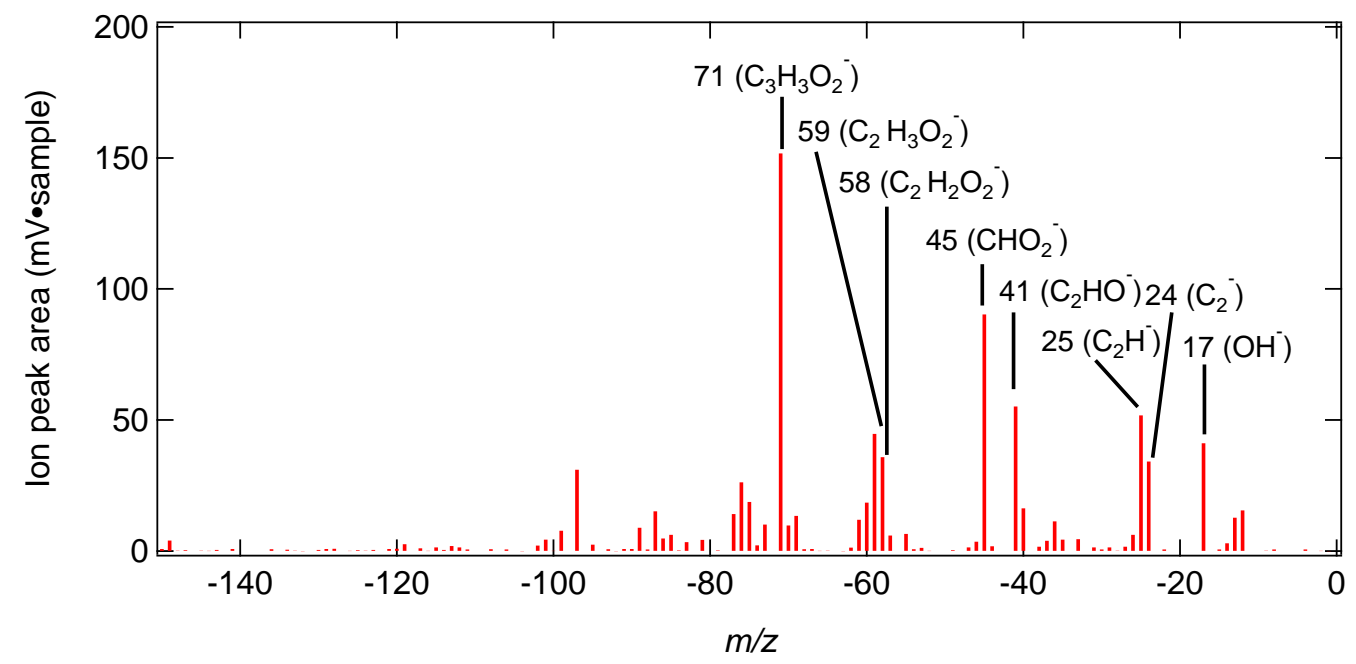

Figure S7. Mean anion spectrum of levoglucosan, obtained as the difference between the mean spectrum of levoglucosan with $\mathrm{KSO}_{4}$ (average of 754 single particle spectra analyzed by the ALABAMA) and the pure $\mathrm{KSO}_{4}$ mean spectrum (see Fig. S4).

Table S1. Organic compounds showing isobaric interferences with fragments of levoglucosan.

\begin{tabular}{lll}
\hline Compounds & $\begin{array}{l}\text { Ion } \\
\text { markers }\end{array}$ & References \\
\hline Acetic acid & $\mathrm{m} / \mathrm{z}-59$ & Lee et al. (2003); Brands et al. (2011) \\
Methylglyoxal & $\mathrm{m} / \mathrm{z}-71$, & Zauscher et al. (2013)* \\
& $\mathrm{m} / \mathrm{z}-59$ & Zauscher et al. (2013)* \\
Acrylate & $\mathrm{m} / \mathrm{z}-71$ & Zauscher et al. (2013)* \\
Glyoxylic acid & $\mathrm{m} / \mathrm{z}-73$ & Lee et al. (2003); Zauscher et al. (2013) \\
Polycyclic aromatic hydrocarbons & $\mathrm{m} / \mathrm{z}-25$ & Silva and Prather (2000) \\
Polycyclic aromatic hydrocarbons & $\mathrm{m} / \mathrm{z}-41$ & Silva and Prather (2000) \\
-cont. alkohol functional groups & $\mathrm{m} / \mathrm{z}-41$ & Silva and Prather (2000) \\
Formic acid & $\mathrm{m} / \mathrm{z}-45$ & Lee et al. (2003) \\
Ethoxide & $\mathrm{m} / \mathrm{z}-45$ & Lee et al. (2003) \\
n-propoxide & $\mathrm{m} / \mathrm{z}-59$ & Lee et al. (2003) \\
Propanoic acid & $\mathrm{m} / \mathrm{z}-73$ & Lee et al. (2003) \\
\hline
\end{tabular}

*Zauscher et al. (2013, Supplement) further reported that most oxygen-containing organic standards show small ion peaks at $\mathrm{m} / \mathrm{z}-45$ and $\mathrm{m} / \mathrm{z}-59$. 


\section{S5 Internal mixing of particle types}

The internal mixing state of the ALABAMA particle types is given in Table S2. Additionally, the expanded mean anion spectrum of those sea spray particles that are internally mixed with DCA compounds are shown in Fig. S5. The remaining particles in Fig. 4 (gray filling) are further sub-classified with marker species: ammonium, methanesulfonic acid, and sulfate (see Fig. S5). Figure S5 depicts the bipolar mean spectrum of particles that could not classified with the marker species, so-called "Others". 
Table S2. Particle types and their internal mixing with other substances derived from the mean spectra in Fig. 5. Additional ion signals of sulfate $\left(m / z-97 / 99\left(\mathrm{HSO}_{4}^{-}\right),-96\left(\mathrm{SO}_{4}^{-}\right)\right)$and potassium $\left(\mathrm{m} / z+39 / 41\left(\mathrm{~K}^{+}\right)\right)$were present in every mean spectrum and have therefore not been listed here. References from SPMS laboratory and field studies are indicated by numbers that are defined below. These references are used for the assignment of the additional ion signals to the corresponding substances.

\begin{tabular}{|c|c|c|c|}
\hline $\begin{array}{l}\text { Particle type } \\
\text { denotation }\end{array}$ & Ion markers & $\begin{array}{l}\text { Additional ion signals } \\
\text { in mean spectrum }\end{array}$ & $\begin{array}{l}\text { Corresponding } \\
\text { substances }\end{array}$ \\
\hline $\begin{array}{l}\mathrm{Na} / \mathrm{Cl} / \\
\text { Nitrate } \\
\text {-containing }\end{array}$ & $\begin{array}{l}m / z+23\left(\mathrm{Na}^{+}\right),+46\left(\mathrm{Na}_{2}^{+}\right) \\
+62\left(\mathrm{Na}_{2} \mathrm{O}^{+}\right),+63\left(\mathrm{Na}_{2} \mathrm{OH}^{+}\right) \\
+81 / 83\left(\mathrm{Na}_{2} \mathrm{Cl}^{+}\right) \\
m / z-35 / 37\left(\mathrm{Cl}^{-}\right) \\
-46\left(\mathrm{NO}_{2}^{-}\right),-62\left(\mathrm{NO}_{3}^{-}\right), \\
-93 / 95\left(\mathrm{NaCl}_{2}^{-}\right)\end{array}$ & $\begin{array}{l}m / z+24 / 25 / 26\left(\mathrm{Mg}^{+}\right) \\
+40\left(\mathrm{Ca}^{+}\right),+56\left(\mathrm{CaO}^{+}\right) \\
m / z-26\left(\mathrm{CN}^{-}\right),-42\left(\mathrm{CNO}^{-}\right) \\
-45\left(\mathrm{CHO}_{2}^{-}\right),-59\left(\mathrm{C}_{2} \mathrm{H}_{3} \mathrm{O}_{2}^{-}\right) \\
-71\left(\mathrm{C}_{3} \mathrm{H}_{3} \mathrm{O}_{2}^{-}\right),-73\left(\mathrm{C}_{3} \mathrm{H}_{5} \mathrm{O}_{2}^{-}\right) \\
-89\left(\mathrm{C}_{2} \mathrm{HO}_{4}^{-}\right)\end{array}$ & $\begin{array}{l}\text { magnesium }^{1,2} \\
\text { calcium } \\
\text { nitrogen-cont. } \mathrm{OM}^{1,2,3} \\
\text { oxygen-cont. } \mathrm{OM}^{3,4,5} \\
\text { oxalic acid }^{9}\end{array}$ \\
\hline $\begin{array}{l}\text { EC } \\
\text {-containing }\end{array}$ & $\begin{array}{l}m / z+12,+24, \ldots,+84\left(\mathrm{C}_{1-7}^{+}\right) \\
m / z-12,-24, \ldots,-96\left(\mathrm{C}_{1-8}^{-}\right)\end{array}$ & $\begin{array}{l}m / z-26\left(\mathrm{CN}^{-}\right),-42\left(\mathrm{CNO}^{-}\right), \\
-45\left(\mathrm{CHO}_{2}^{-}\right),-59\left(\mathrm{C}_{2} \mathrm{H}_{3} \mathrm{O}_{2}^{-}\right), \\
-73\left(\mathrm{C}_{3} \mathrm{H}_{5} \mathrm{O}_{2}^{-}\right) \\
-89\left(\mathrm{C}_{2} \mathrm{HO}_{4}^{-}\right) \\
-95\left(\mathrm{CH}_{3} \mathrm{O}_{3} \mathrm{~S}^{-}\right) \\
-46\left(\mathrm{NO}_{2}^{-}\right),-62\left(\mathrm{NO}_{3}^{-}\right)\end{array}$ & $\begin{array}{l}\text { nitrogen-cont. } \mathrm{OM}^{6} \\
\text { oxygen-cont. } \mathrm{OM}^{8,10} \\
\text { oxalic acid } \\
\text { MSA }^{9} \\
\text { nitrate }^{9}\end{array}$ \\
\hline $\begin{array}{l}\text { nss-nitrate } \\
\text {-containing }\end{array}$ & $m / z-46\left(\mathrm{NO}_{2}^{-}\right),-62\left(\mathrm{NO}_{3}^{-}\right)$ & $\begin{array}{l}m / z-26\left(\mathrm{CN}^{-}\right),-42\left(\mathrm{CNO}^{-}\right) \\
-45\left(\mathrm{CHO}_{2}^{-}\right),-59\left(\mathrm{C}_{2} \mathrm{H}_{3} \mathrm{O}_{2}^{-}\right) \\
-73\left(\mathrm{C}_{3} \mathrm{H}_{5} \mathrm{O}_{2}^{-}\right) \\
-89\left(\mathrm{C}_{2} \mathrm{HO}_{4}^{-}\right)\end{array}$ & $\begin{array}{l}\text { nitrogen-cont. } \mathrm{OM}^{6} \\
\text { oxygen-cont. } \mathrm{OM}^{8,10} \\
\text { oxalic acid }^{9}\end{array}$ \\
\hline $\begin{array}{l}\text { TMA } \\
\text {-containing }\end{array}$ & $\begin{array}{l}m / z+59\left(\left(\mathrm{CH}_{3}\right)_{3} \mathrm{~N}^{+}\right) \\
+58\left(\mathrm{C}_{3} \mathrm{H}_{8} \mathrm{~N}^{+}\right)\end{array}$ & $\begin{array}{l}m / z+18\left(\mathrm{NH}_{4}^{+}\right) \\
+12, \ldots,+36\left(\mathrm{C}_{1-3}^{+}\right), \\
+27\left(\mathrm{C}_{2} \mathrm{H}_{3}^{+} / \mathrm{CHN}^{+}\right) \\
+37\left(\mathrm{C}_{3} \mathrm{H}^{+}\right) \\
+43\left(\mathrm{C}_{3} \mathrm{H}_{7}^{+} / \mathrm{CH}_{3} \mathrm{CO}^{+} /\right. \\
\left.\mathrm{CHNO}^{+}\right) \\
m / z-95\left(\mathrm{CH}_{3} \mathrm{O}_{3} \mathrm{~S}^{-}\right)\end{array}$ & $\begin{array}{l}\text { ammonium }^{9} \\
\text { carbon cluster ions }^{9} \\
\text { hydrocarbons }^{7} \\
\text { oxidized organics }^{7} \\
\text { MSA }^{9}\end{array}$ \\
\hline $\begin{array}{l}\text { DCA } \\
\text {-containing }\end{array}$ & $\begin{array}{l}m / z-89\left(\mathrm{C}_{2} \mathrm{HO}_{4}^{-}\right), \\
-103\left(\mathrm{C}_{3} \mathrm{H}_{3} \mathrm{O}_{4}^{-}\right) \\
-117\left(\mathrm{C}_{4} \mathrm{H}_{5} \mathrm{O}_{4}^{-}\right)\end{array}$ & $\begin{array}{l}m / z+27\left(\mathrm{C}_{2} \mathrm{H}_{3}^{+} / \mathrm{CHN}^{+}\right) \\
m / z-26\left(\mathrm{CN}^{-}\right),-42\left(\mathrm{CNO}^{-}\right) \\
-45\left(\mathrm{CHO}_{2}^{-}\right),-59\left(\mathrm{C}_{2} \mathrm{H}_{3} \mathrm{O}_{2}^{-}\right) \\
-73\left(\mathrm{C}_{3} \mathrm{H}_{5} \mathrm{O}_{2}^{-}\right)\end{array}$ & $\begin{array}{l}\text { hydrocarbons }{ }^{7} \\
\text { nitrogen-cont. } \mathrm{OM}^{6} \\
\text { oxygen-cont. } \mathrm{OM}^{8,10}\end{array}$ \\
\hline $\begin{array}{l}\text { sub-K } \\
\text {-containing }\end{array}$ & $m / z+39 / 41\left(\mathrm{~K}^{+}\right)$ & $\begin{array}{l}m / z+18\left(\mathrm{NH}_{4}^{+}\right), \\
+12, \ldots,+36\left(\mathrm{C}_{1-3}^{+}\right), \\
+27\left(\mathrm{C}_{2} \mathrm{H}_{3}^{+} / \mathrm{CHN}^{+}\right), \\
+37\left(\mathrm{C}_{3} \mathrm{H}^{+}\right) \\
+43\left(\mathrm{C}_{3} \mathrm{H}_{7}^{+} / \mathrm{CH}_{3} \mathrm{CO}^{+} /\right. \\
\left.\mathrm{CHNO}^{+}\right) \\
m / z-95\left(\mathrm{CH}_{3} \mathrm{O}_{3} \mathrm{~S}^{-}\right)\end{array}$ & $\begin{array}{l}\text { ammonium }^{9} \\
\text { carbon cluster ions } \\
\text { hydrocarbons } \\
\end{array}$ \\
\hline
\end{tabular}

Given reference numbers are defined as follows: ${ }^{(1)}$ Prather et al. $(2013),{ }^{(2)}$ Guasco et al. (2014), ${ }^{(3)}$ Pratt et al. $(2009),{ }^{(4)}$ Schmidt et al. (2017), ${ }^{(5)}$ Trimborn et al. (2002), ${ }^{(6)}$ Silva et al. (1999), ${ }^{(7)}$ Schmidt (2015), ${ }^{(8)}$ Zauscher et al. (2013), ${ }^{(9)}$ see Table 1, ${ }^{(10)}$ Lee et al. (2003). 


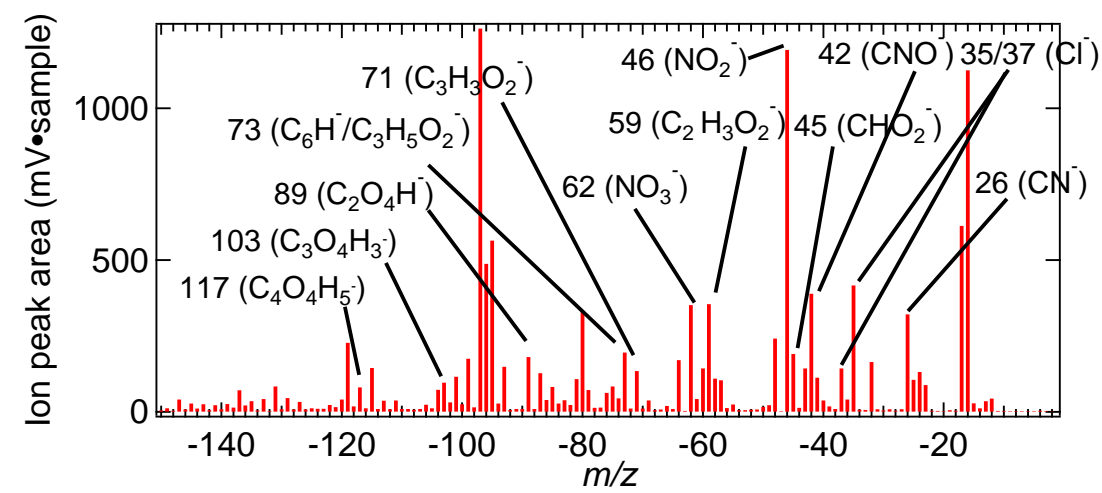

Figure S8. Expanded mean anion spectrum of sea spray particles containing DCA, presenting 60\% of all sea spray particles in Fig. 5a. 


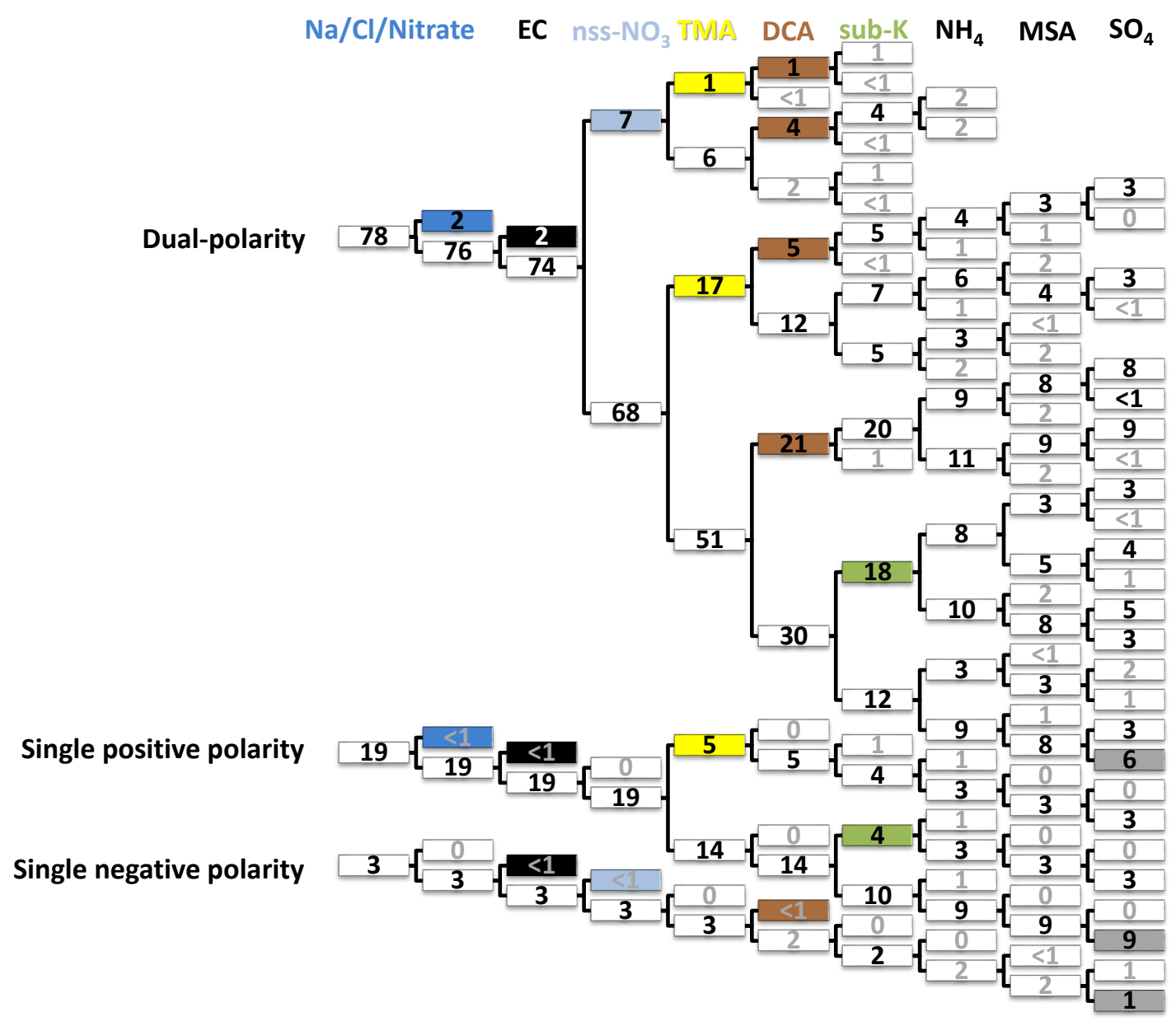

Figure S9. Classification of 10137 single particle spectra based on the ion marker method and illustrated with the decision tree. Upper/lower branches refer to the presence/absence of substances in the particle mass spectra. Numbers are given as relative abundances in $\%$ normalized to 10137 particles. The initial classification provides three groups of particle mass spectra with dual-, single positive, and single negative polarity. Particle types, indicated by colors, contain: $\mathrm{Na} / \mathrm{Cl} / \mathrm{Nitrate}$ (dark blue), EC (black), non-sea-spray-(nss)- $\mathrm{NO}_{3}$ (light blue), trimethylamine (TMA) (yellow), dicarboxylic acids (DCA) (brown), and potassium (sub-K) (green). The remaining particles are further sub-classified by the abundance of ammonium $\left(\mathrm{NH}_{4}\right)$, methanesulfonic acid (MSA), and sulfate $\left(\mathrm{SO}_{4}\right) .16 \%$ of all mass spectra could not be classified with the marker species, summarized as "Others" and marked with a gray filling. 


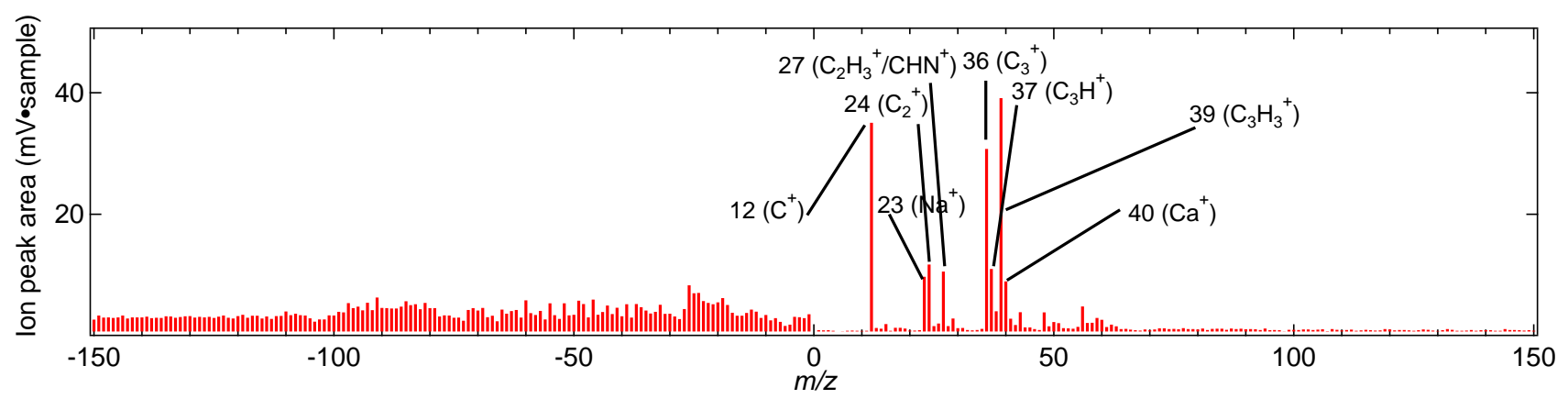

Figure S10. Bipolar mean spectrum of the 1618 particles (16\% of all mass spectra analyzed by the ALABAMA) that could not classified with the marker species (see gray filling in Fig. S5). These particles are therefore summarized as "Others".

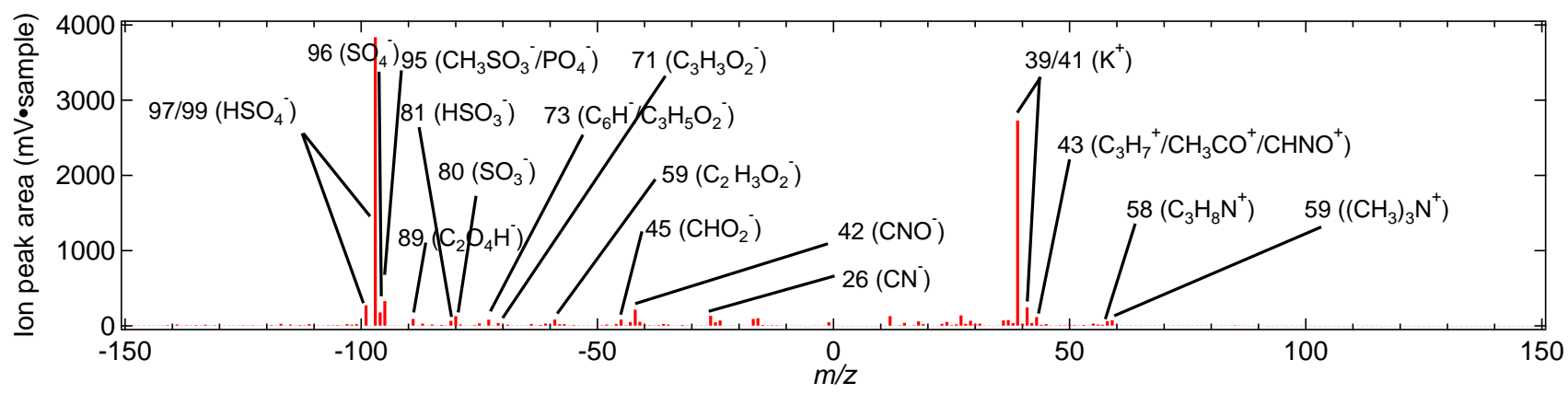

Figure S11. Bipolar mean spectrum of particles that show internal mixing of DCA, TMA, and MSA (14\% of all DCA-containing particles, $4 \%$ of all mass spectra analyzed by the ALABAMA).

\section{S6 Additional figures}

Figures S6 - S6 are associated with the discussion in Sections 3.2.2-3.2.3 and 3.3.2 in the main document. 


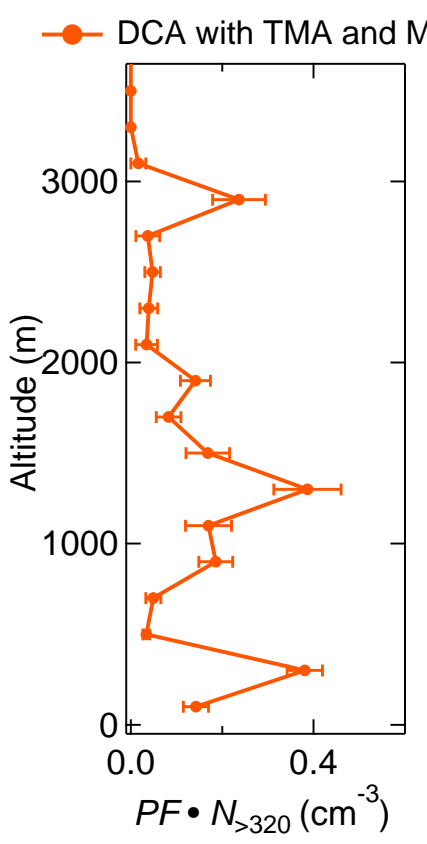

Figure S12. Vertically resolved aerosol composition measured by the ALABAMA during the Arctic air mass period. The panel represents the ALABAMA scaled number concentration $\left(P F \cdot N_{>320}\right)$ of particles that show internal mixing of DCA, TMA, and MSA. Uncertainty analyses are given in the Supplement Sect. 7.

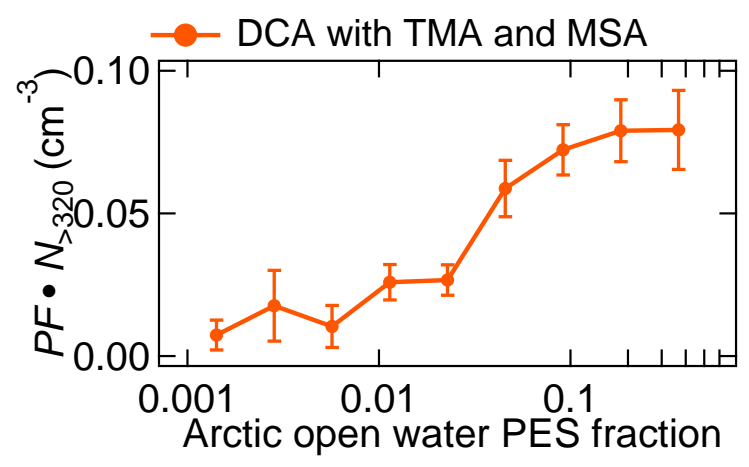

Figure S13. Aerosol composition measured by the ALABAMA as a function of FLEXPART derived PES fraction over Arctic open water areas during the Arctic air mass period. The panel represents the ALABAMA scaled number concentration $\left(P F \cdot N_{>320}\right)$ of particles that show internal mixing of DCA, TMA, and MSA. Uncertainty analyses are given in the Supplement Sect. 7. 
(a)
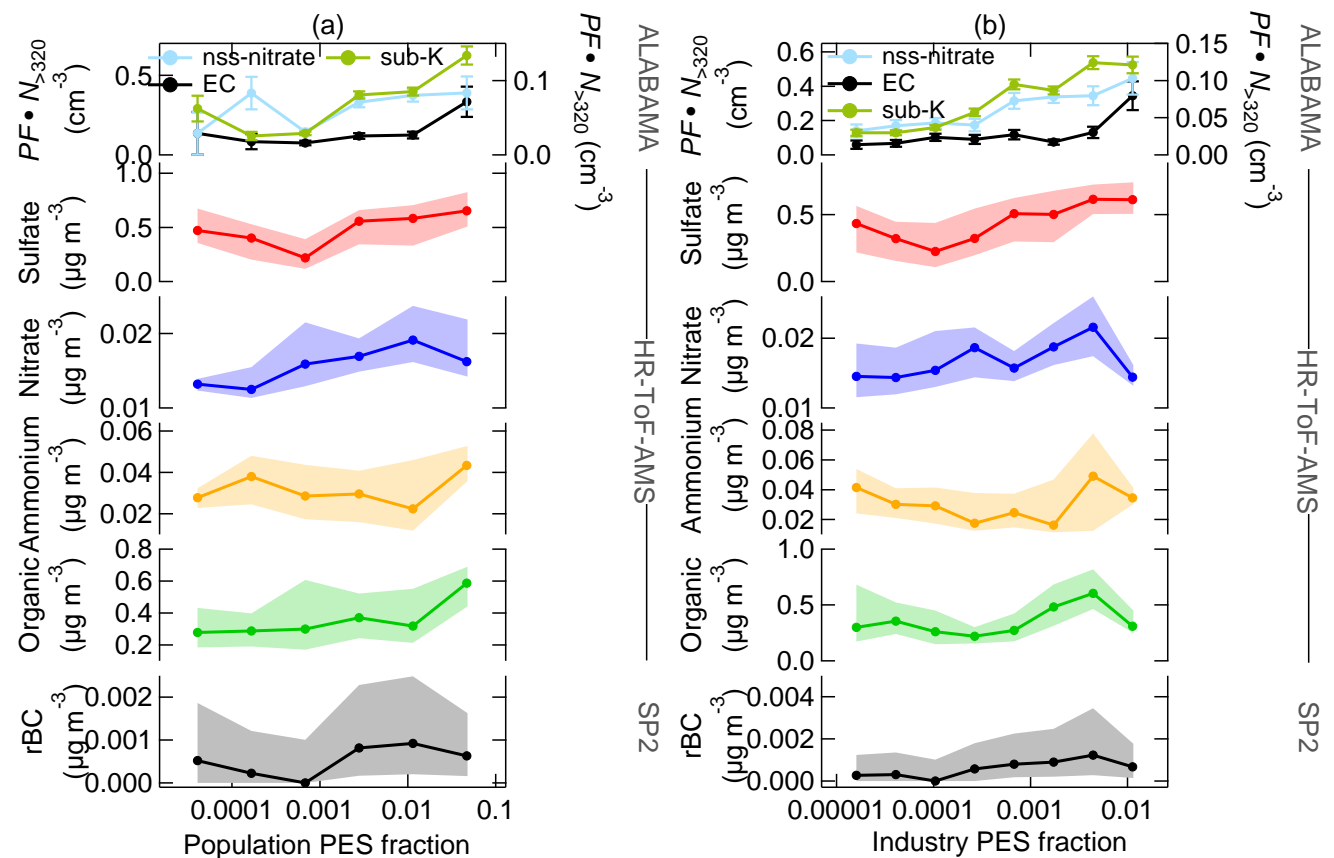

Figure S14. Aerosol composition measured by the ALABAMA and by the HR-ToF-AMS (indicated on the right side) as a function of FLEXPART derived PES fraction over (a) populated areas and (b) industrial areas during the Arctic air mass period. Top panel represents the ALABAMA scaled number concentration $\left(P F \cdot N_{>320}\right)$ with right axis referring to EC (black)- and nss-nitrate (light blue)-containing particles and left axis referring to sub-K-containing (green) particles. Lower panels represent each median (solid line with marker) and interquartile ranges (shaded area) of the HR-ToF-AMS mass concentrations of sulfate (red), nitrate (blue), ammonium (orange), and organic matter (light green) as well as rBC measured by the SP2 (black). Uncertainty analyses are given in the Supplement Sect. 7.

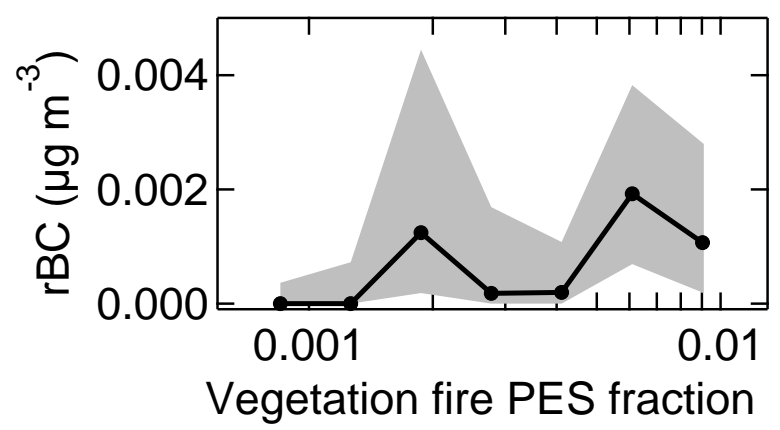

Figure S15. Refractory black carbon (rBC) measured by the SP2 as a function of FLEXPART derived PES fraction over vegetation fires during the southern air mass period. The figure represents median (solid line with marker) and interquartile ranges (shaded area). Uncertainty analyses are given in the Supplement Sect. 7.

Figures S6-S6 provide the cumulative fraction of the ALABAMA aerosol composition, associated with figures of the scaled number concentration in the main document. 


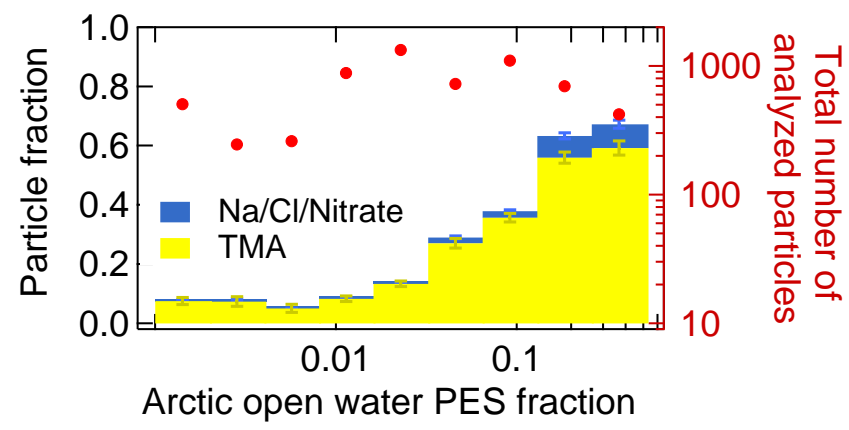

Figure S16. Aerosol composition measured by the ALABAMA as a function of FLEXPART derived PES fraction over Arctic open water areas during the Arctic air mass period. The figure represents the cumulative particle fraction of TMA-containing (yellow) and Na/Cl/Nitratecontaining (blue) particles as well as the total number of analyzed particles per bin (red). Uncertainty analyses are given in the Supplement Sect. 7.

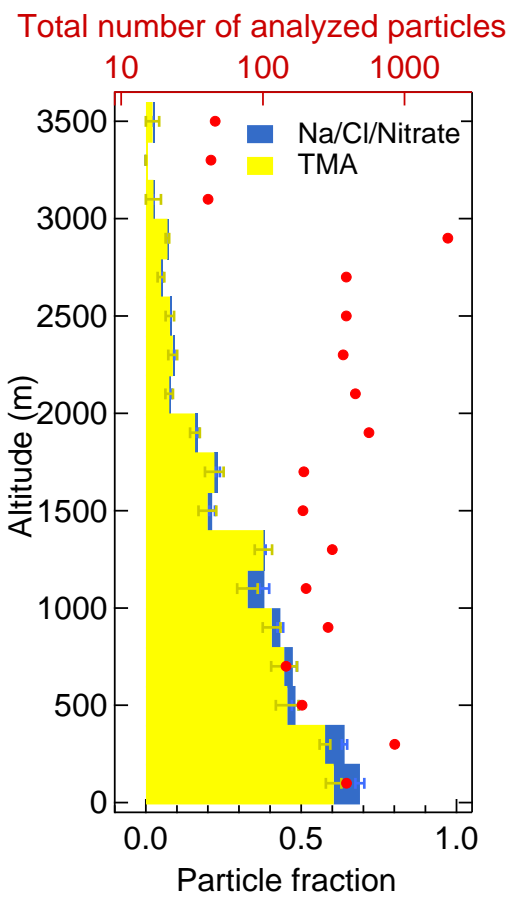

Figure S17. Vertically resolved aerosol composition measured by the ALABAMA during the Arctic air mass period. The figure represents the cumulative particle fraction of TMA-containing (yellow) and $\mathrm{Na} / \mathrm{Cl} / \mathrm{Nitrate}$-containing (blue) particles as well as the total number of analyzed particles per bin (red). Uncertainty analyses are given in the Supplement Sect. 7. 
(a)

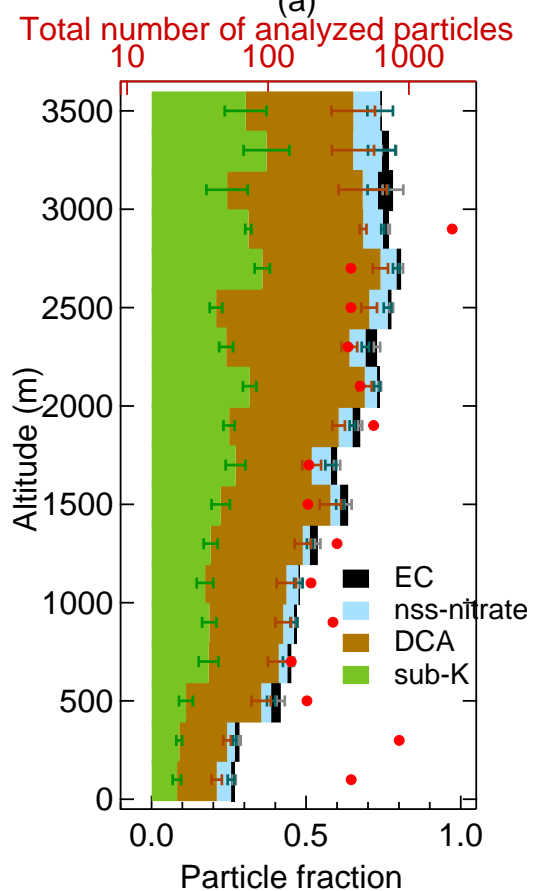

(b)

Total number of analyzed particles

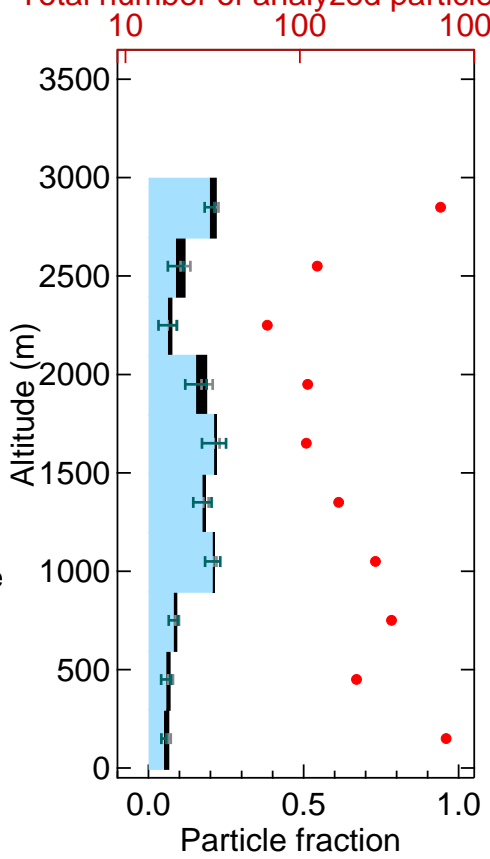

Figure S18. Vertically resolved aerosol composition measured by the ALABAMA during (a) the Arctic air and (b) the southern air mass periods. Figures represent the cumulative particle fraction of DCA- (brown), nss-nitrate- (blue), EC- (black), and sub-K-containing (green) particles as well as the total number of analyzed particles per bin (red). Uncertainty analyses are given in the Supplement Sect. 7. 


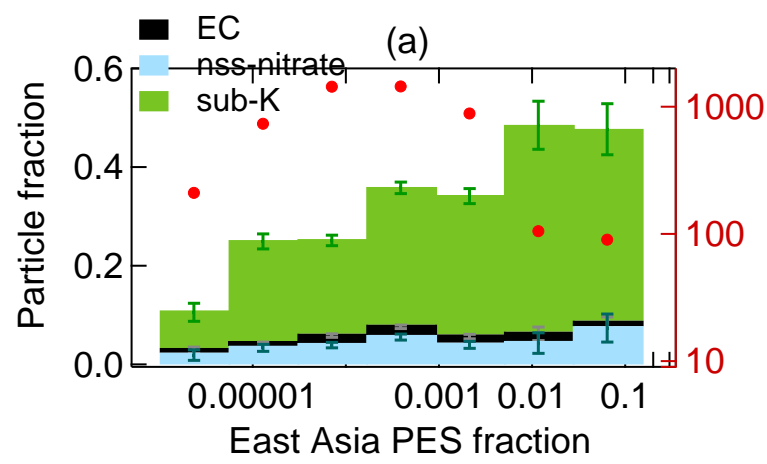

(c)

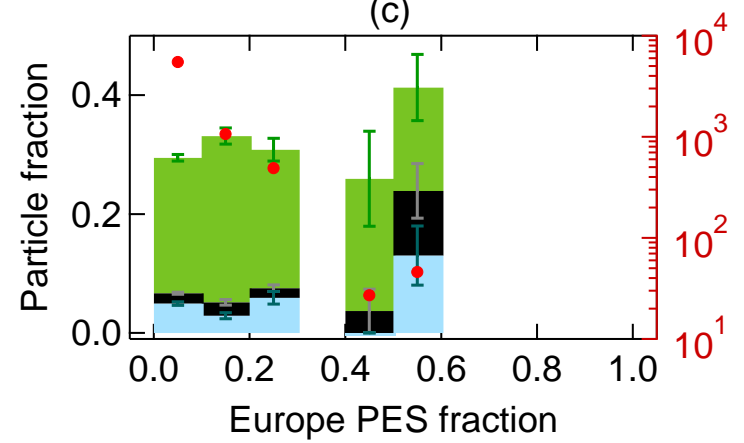

(b)
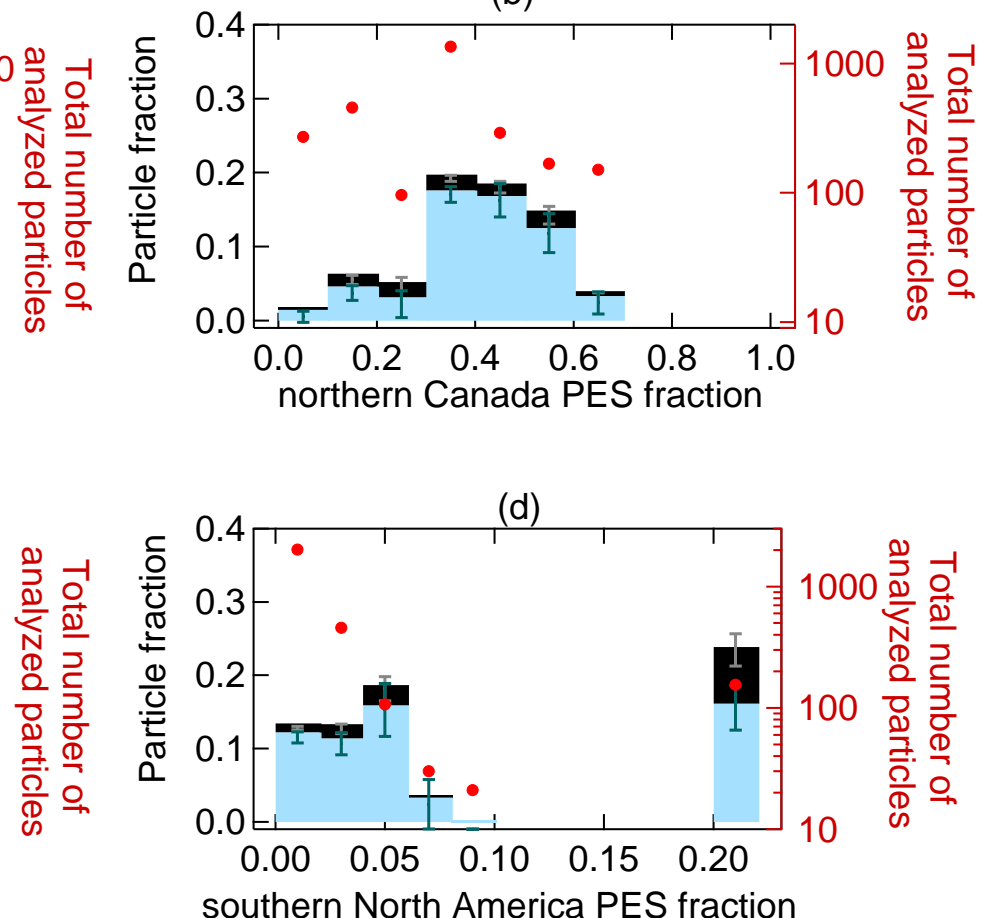

(d)

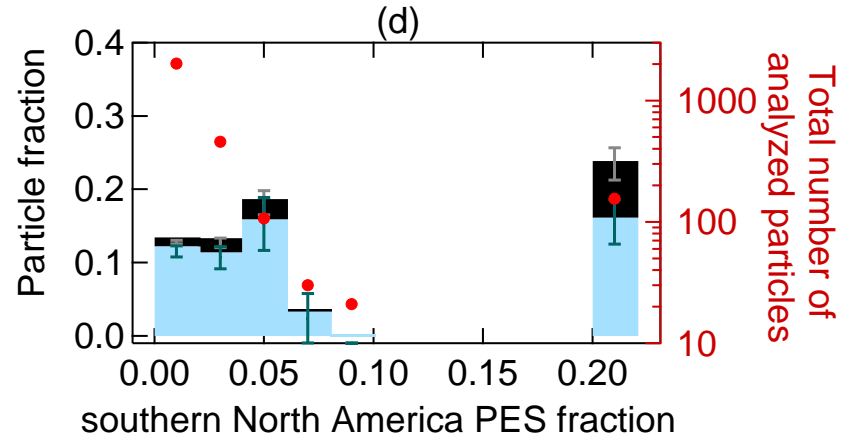

Figure S19. Aerosol composition measured by the ALABAMA as a function of FLEXPART derived PES fraction over the East Asia (a), northern Canada (b), Europe (c), and southern North America (d) during the Arctic (a,c) and the southern air mass (b,d) periods. Figures represent each the cumulative particle fraction of EC- (black), nss-nitrate- (light blue), and sub-K-containing (green) particles as well as the total number of analyzed particles per bin (red). Uncertainty analyses are given in the Supplement Sect. 7. 
(a)

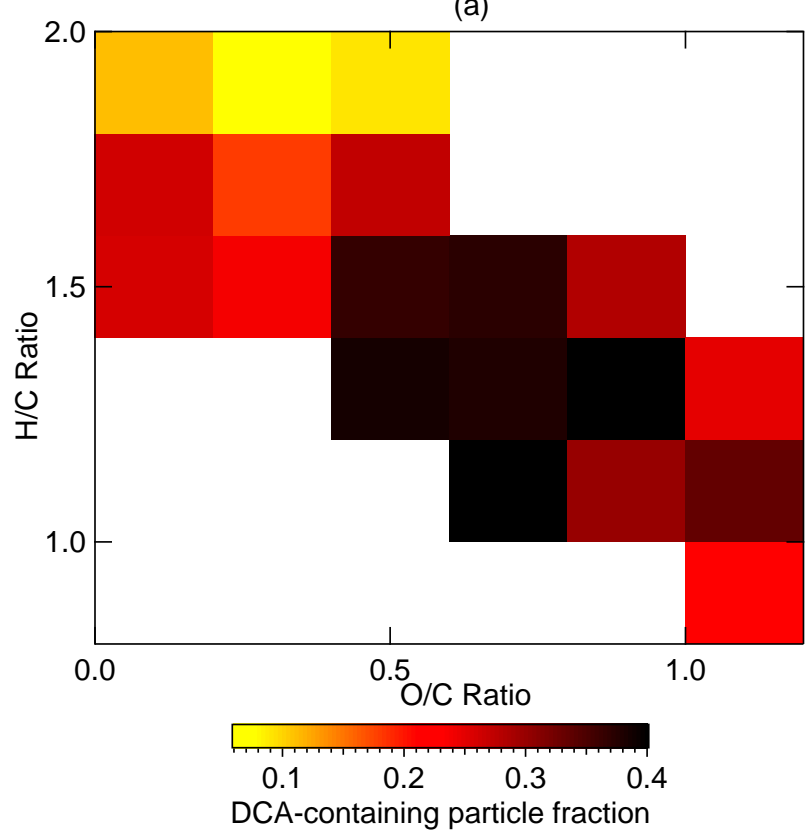

(b)

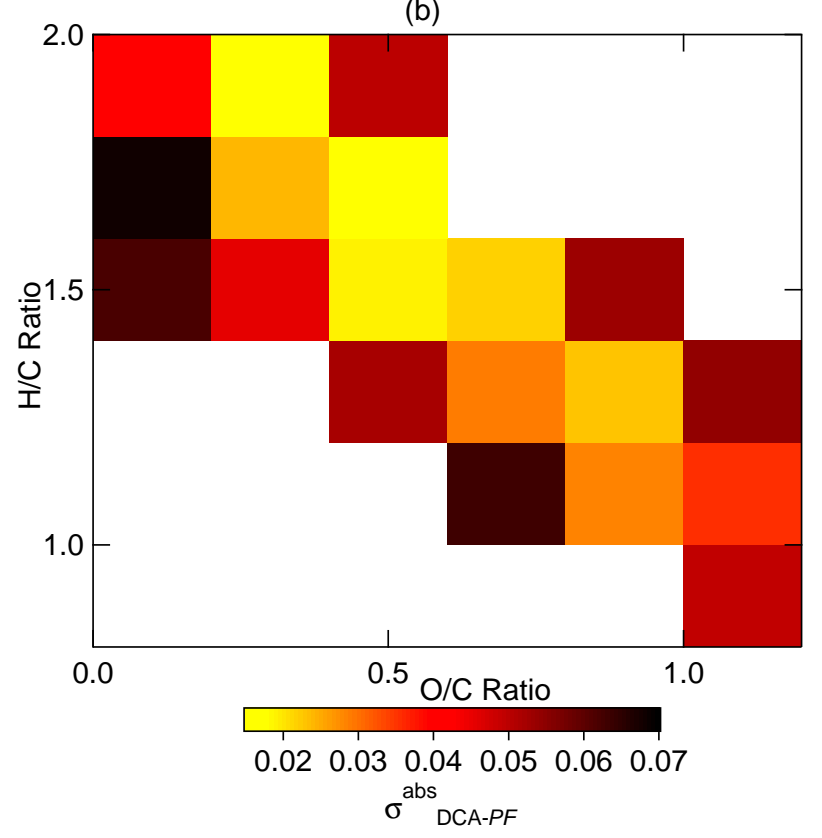

Figure S20. Comparison between the HR-ToF-AMS estimated oxygen-to-carbon $(\mathrm{O} / \mathrm{C})$ and hydrogen-to-carbon $(\mathrm{H} / \mathrm{C})$ ratios colored by (a) the particle fraction of DCA-containing measured by the ALABAMA and (b) the absolute uncertainty of the particle fraction. Uncertainty analyses are given in Sect. 7.

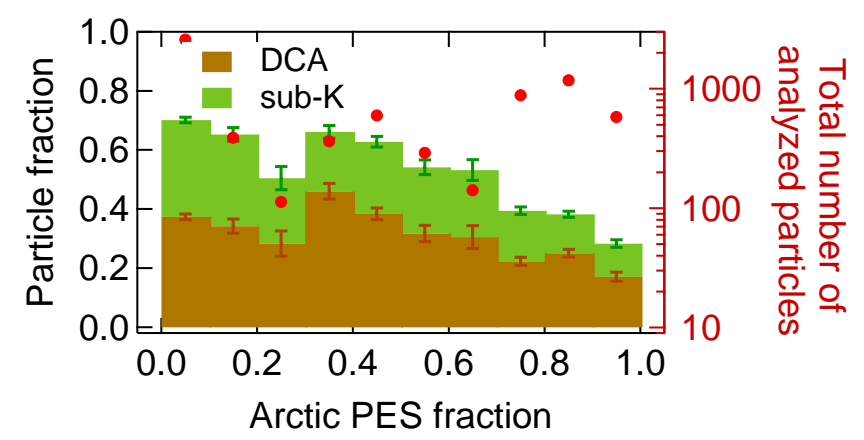

Figure S21. Aerosol composition measured by the ALABAMA as a function of FLEXPART derived PES fraction over Arctic regions during the Arctic air mass period. The figure represents the fraction of DCA- (brown) and sub-K-containing (green) particles as well as the total number of analyzed particles per bin (red). Uncertainty analysis is given in the Supplement Sect. 7. 


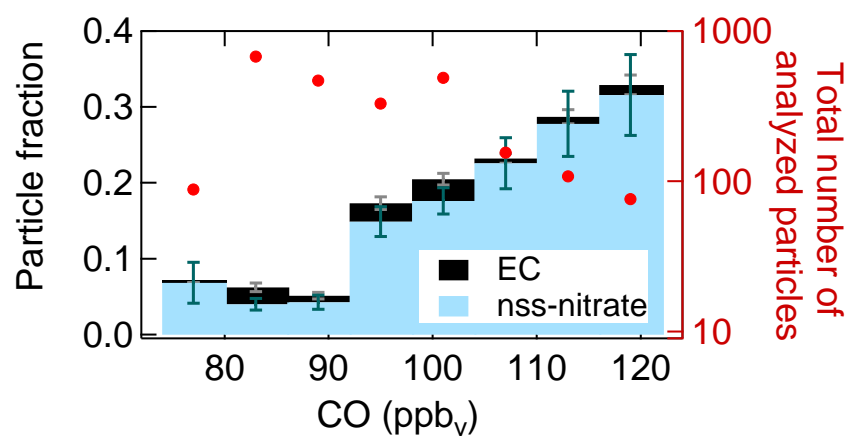

Figure S22. Aerosol composition measured by the ALABAMA as a function of CO mixing ratios during the southern air mass period. Figure represents the cumulative particle fraction of nss-nitrate-containing (blue) and EC-containing (black) particles as well as the total number of analyzed particles per bin (red). Uncertainty analyses are given in the Supplement Sect. 7.

(a)

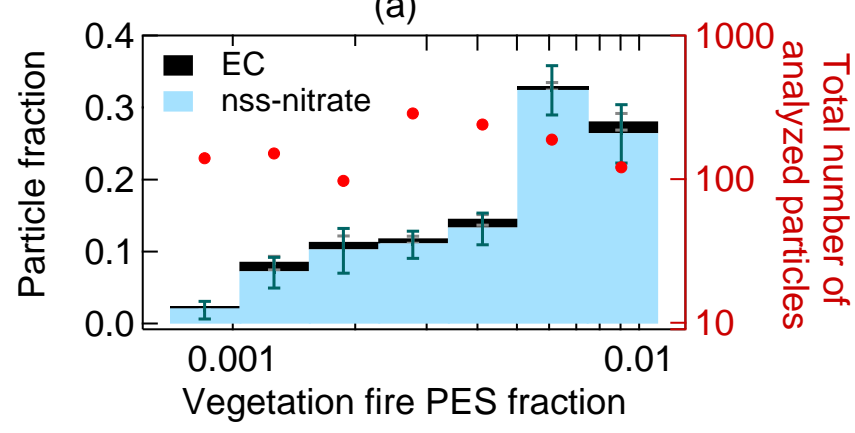

(b)

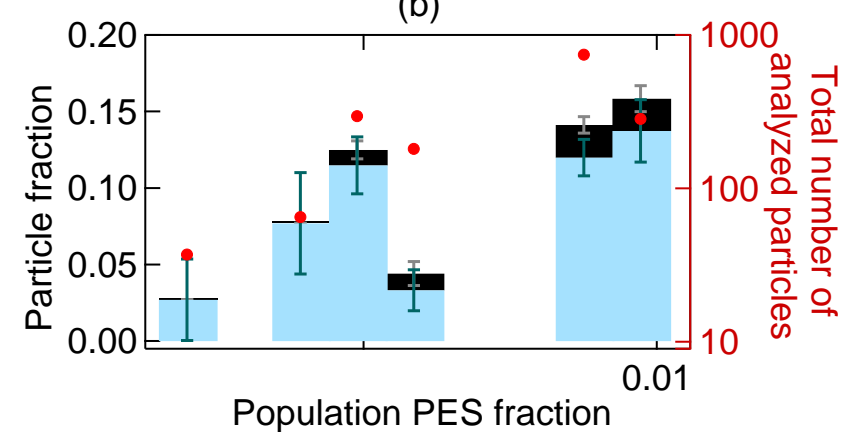

(c)

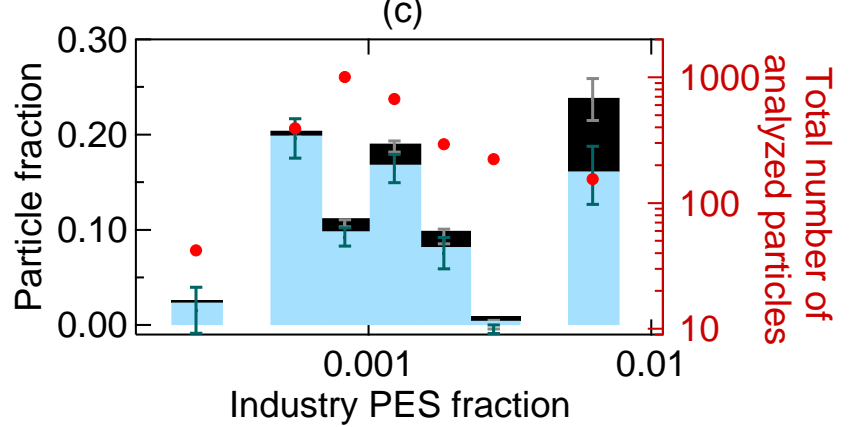

Figure S23. Aerosol composition measured by the ALABAMA as a function of FLEXPART derived PES fraction over (a) vegetation fires, (b) populated areas, and (c) industrial areas during the southern air mass period. Figures represent each the cumulative particle fraction of nss-nitrate-containing (blue) and EC-containing (black) particles as well as the total number of analyzed particles per bin (red). Uncertainty analyses are given in the Supplement Sect. 7. 
(a)

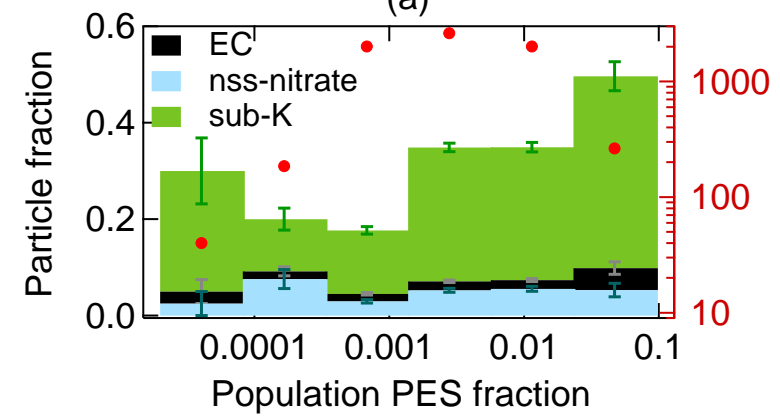

(b)

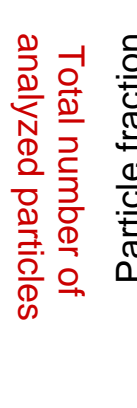

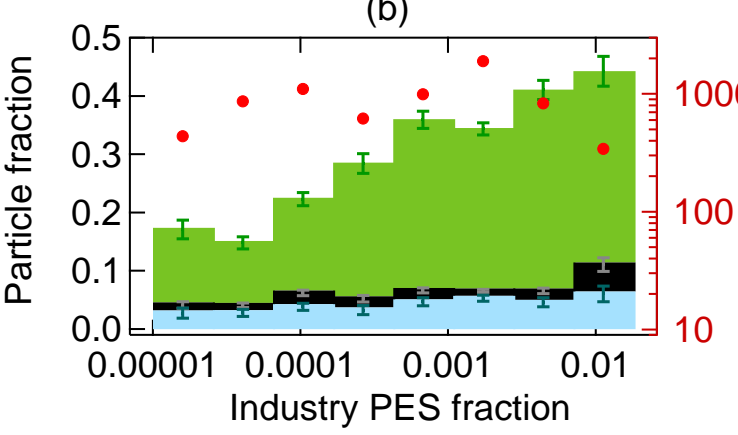

$1000 \stackrel{0}{2}$

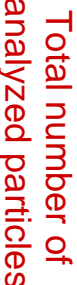

Figure S24. Aerosol composition measured by the ALABAMA as a function of FLEXPART derived PES fraction over (a) populated areas and (b) industrial areas during the Arctic air mass period. Figures represent each the cumulative particle fraction of nss-nitrate-containing (blue), EC-containing (black), and sub-K-containing (green) particles as well as the total number of analyzed particles per bin (red). Uncertainty analyses are given in the Supplement Sect. 7.

Figures S6-S6 provide the comparison between the number concentration of particles larger than $320 \mathrm{~nm}\left(N_{>320}\right)$ measured by the UHSAS and various parameters.

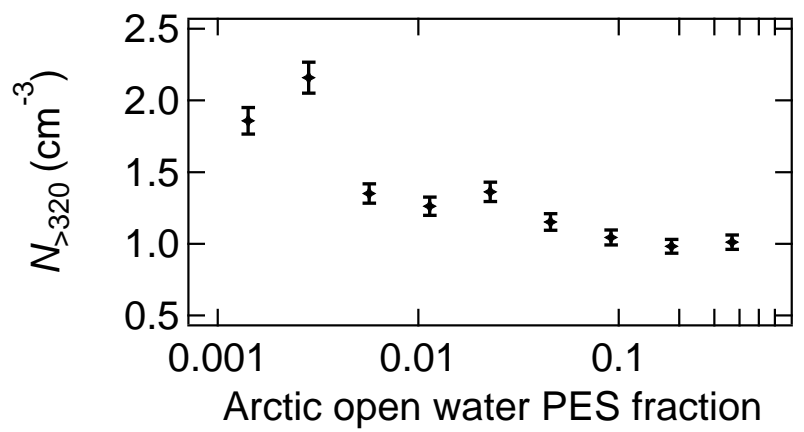

Figure S25. Averaged UHSAS number concentration in a size range between 320 and $870 \mathrm{~nm}\left(N_{>320}\right)$ as a function of FLEXPART derived PES fraction over Arctic open water areas during the Arctic air mass period. Uncertainty analysis is given in Sect. 7. 
(a)

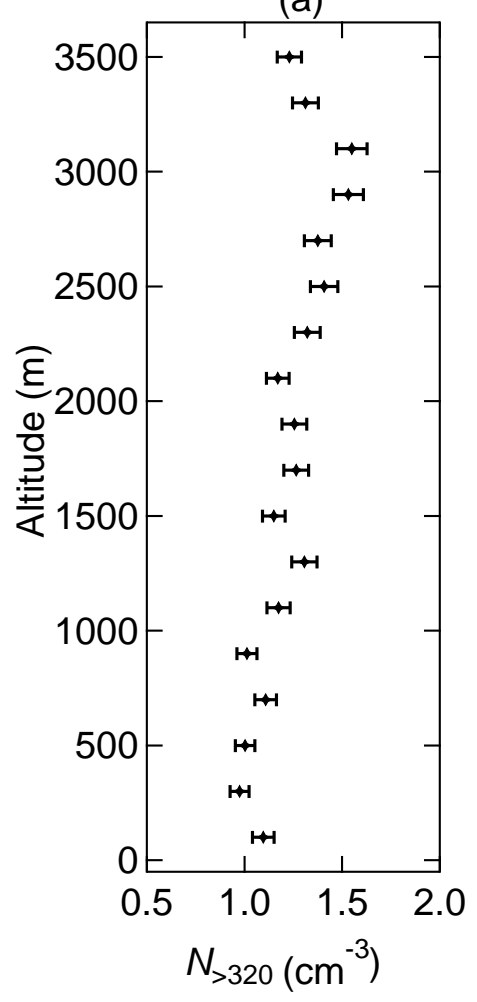

(b)

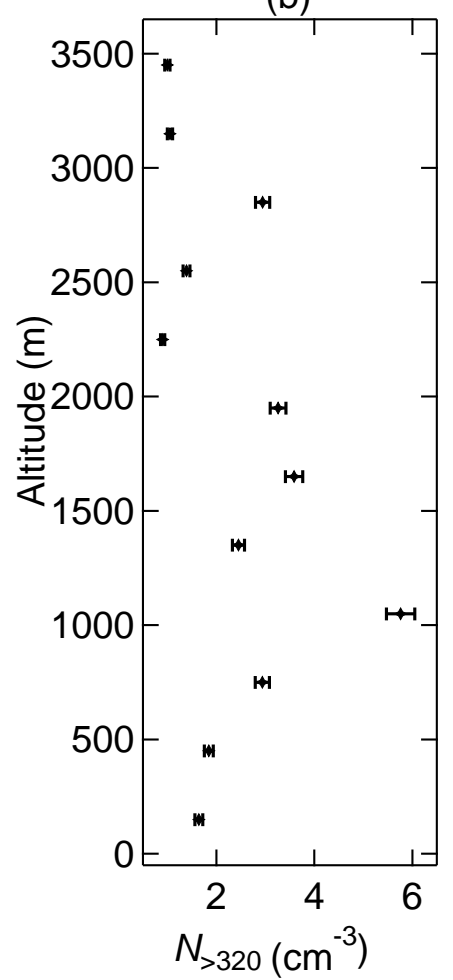

Figure S26. Vertically resolved averaged UHSAS number concentration in a size range between 320 and $870 \mathrm{~nm}\left(N_{>320}\right)$ during the Arctic (a) and the southern (b) air mass periods. Uncertainty analysis is given in Sect. 7. 
(a)

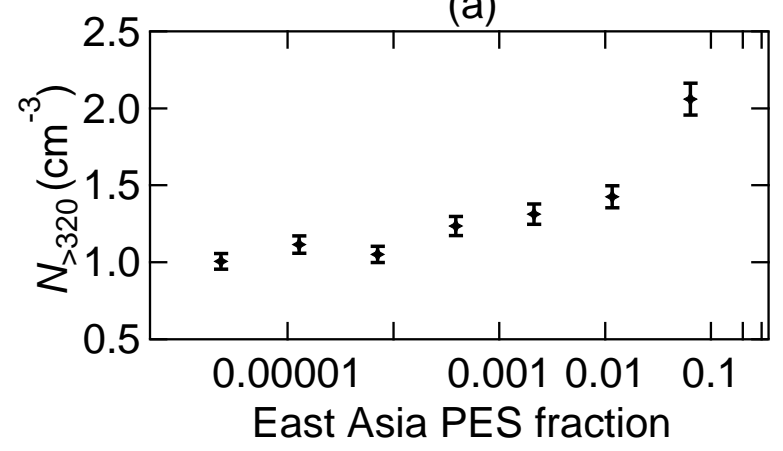

(c)

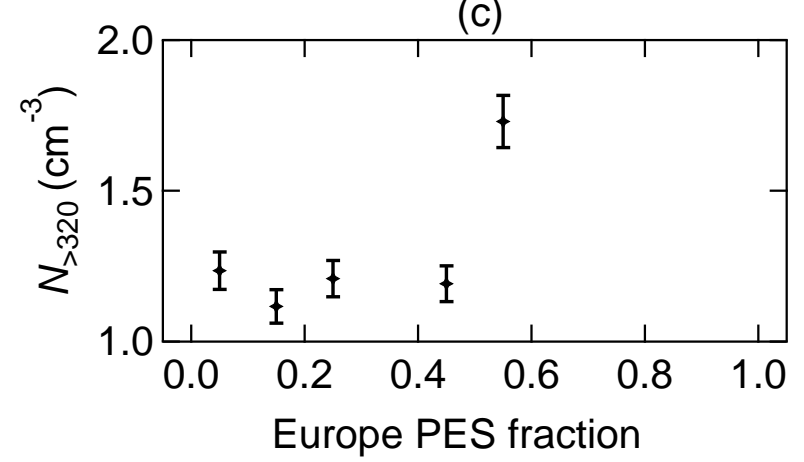

(b)

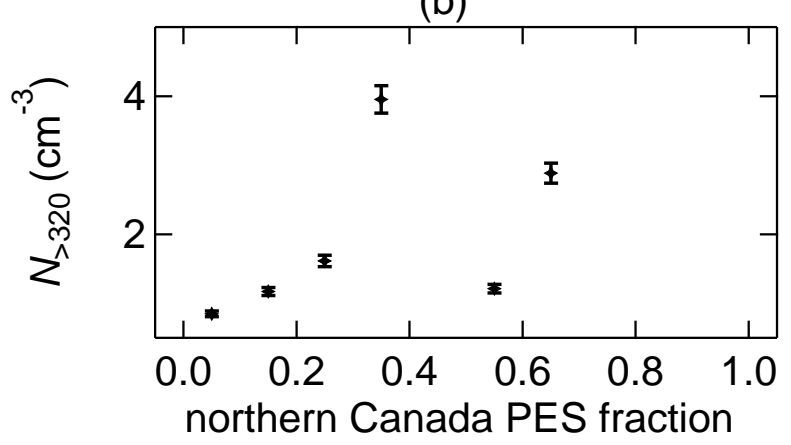

(d)

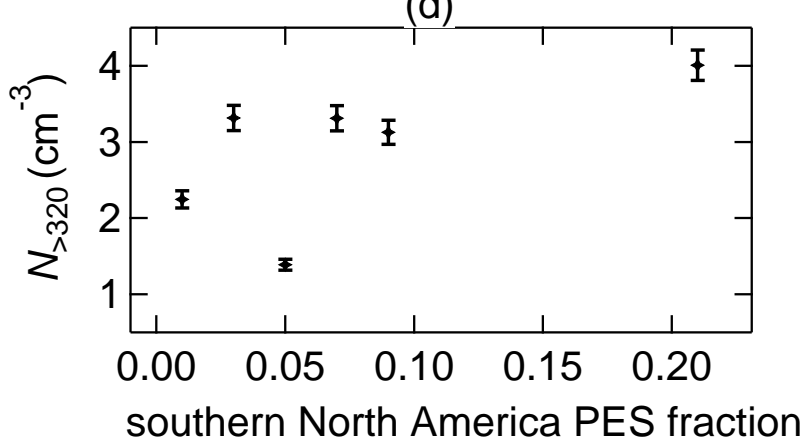

Figure S27. Averaged UHSAS number concentration in a size range between 320 and $870 \mathrm{~nm}\left(N_{>320}\right)$ as a function of FLEXPART derived PES fraction over the East Asia (a), northern Canada (b), Europe (c), and southern North America (d) during the Arctic (a, c) and the southern $(b, d)$ air mass periods. Uncertainty analysis is given in Sect. 7. 
(a)

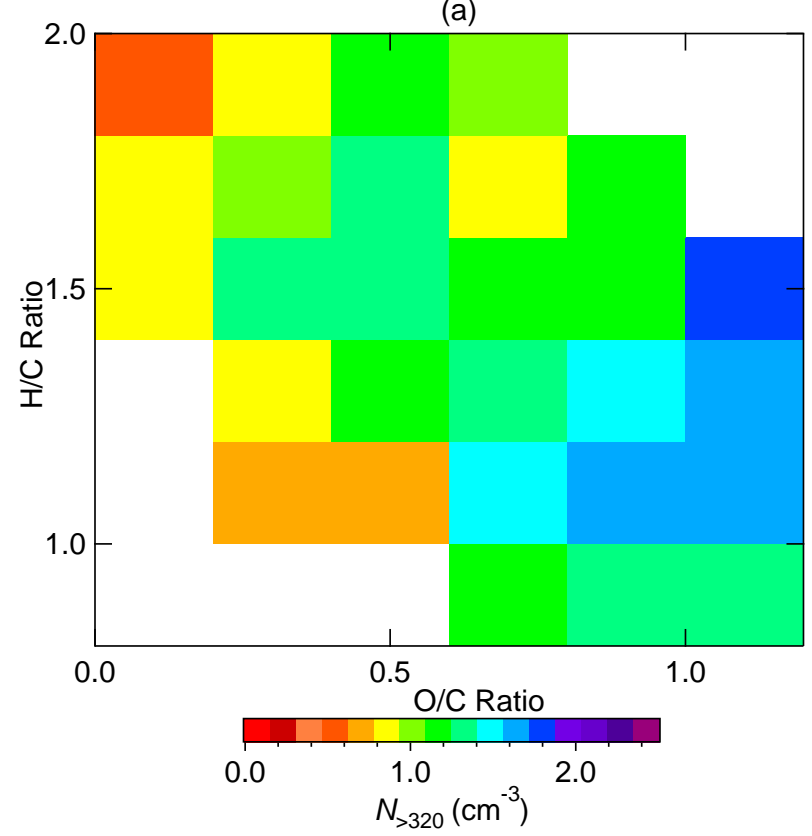

(b)

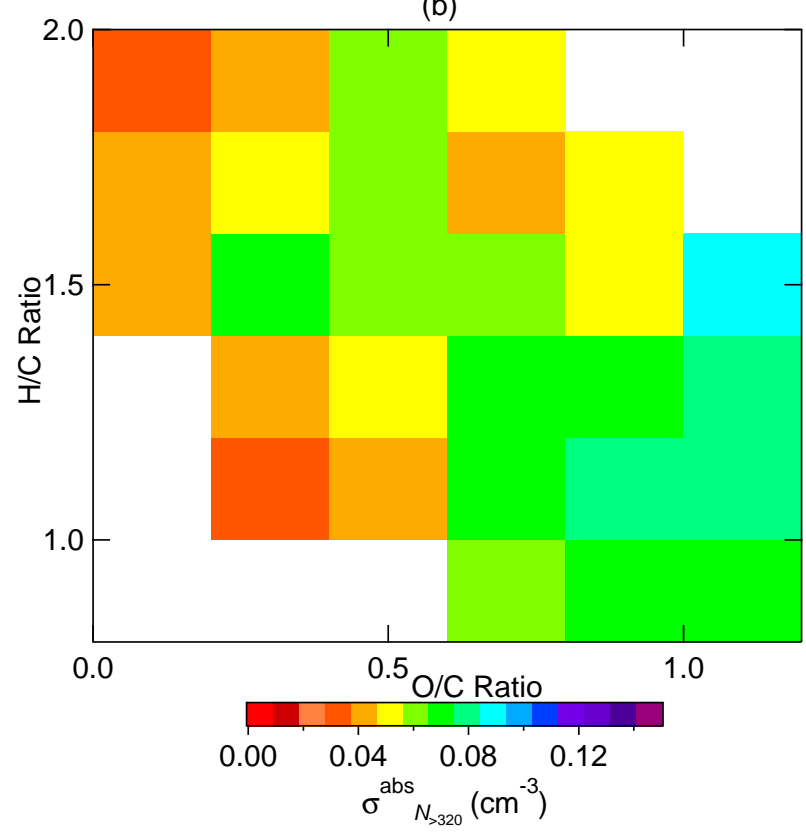

Figure S28. Comparison between the HR-ToF-AMS estimated oxygen-to-carbon $(\mathrm{O} / \mathrm{C})$ and hydrogen-to-carbon (H/C) ratios colored by (a) the averaged UHSAS number concentration in a size range between 320 and $870 \mathrm{~nm}\left(N_{>320}\right)$ and (b) the absolute uncertainty of $N_{>320}$ $\left(\sigma_{N_{>320}}^{\text {abs }}\right)$. Uncertainty analysis is given in Sect. 7.

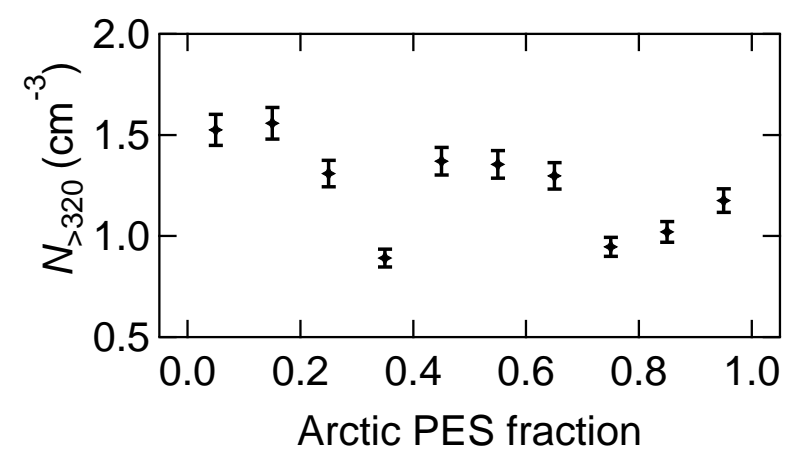

Figure S29. Averaged UHSAS number concentration in a size range between 320 and $870 \mathrm{~nm}\left(N_{>320}\right)$ as a function of FLEXPART derived PES fraction over the Arctic during the Arctic air mass period. Uncertainty analysis is given in Sect. 7. 
(a)

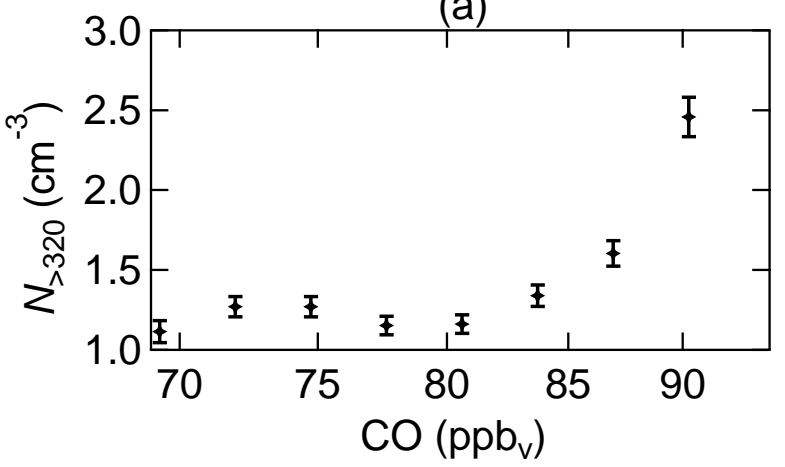

(b)

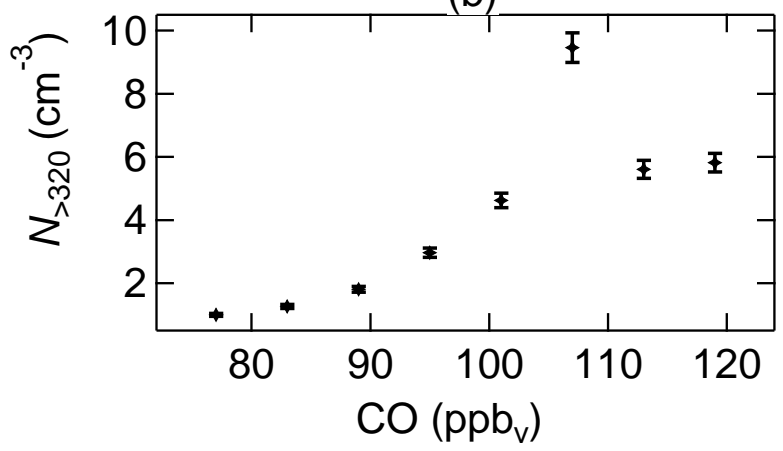

Figure S30. Averaged UHSAS number concentration in a size range between 320 and $870 \mathrm{~nm}\left(N_{>320}\right)$ as a function of CO mixing ratios during the Arctic (a) and the southern (b) air mass periods. Uncertainty analysis is given in Sect. 7.

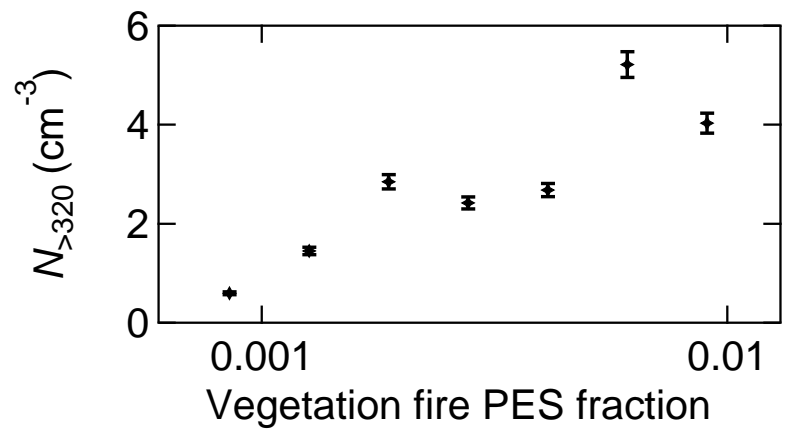

Figure S31. Averaged UHSAS number concentration in a size range between 320 and $870 \mathrm{~nm}\left(N_{>320}\right)$ as a function of FLEXPART derived PES fraction over vegetation fires during the southern air mass period. Uncertainty analysis is given in Sect. 7. 
(a)

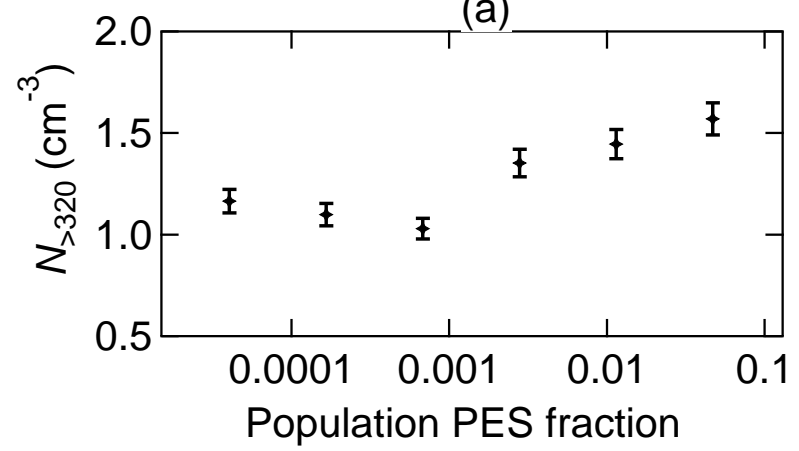

(c)

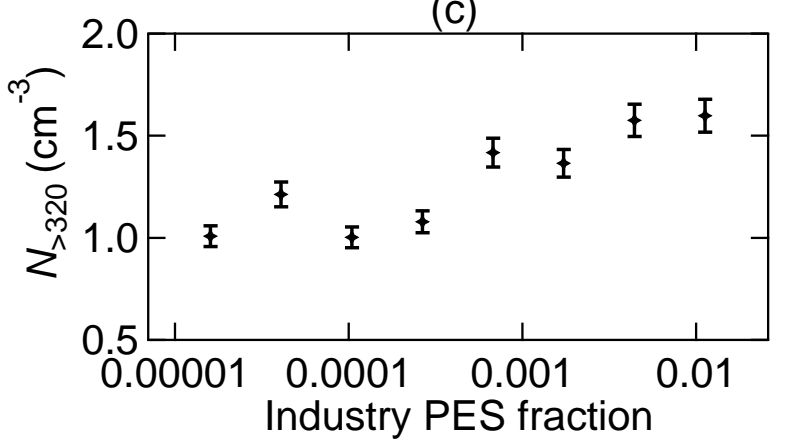

(b)

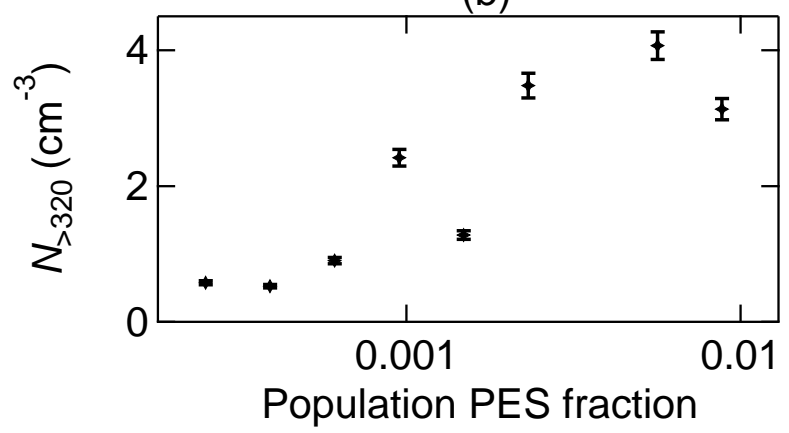

(d)

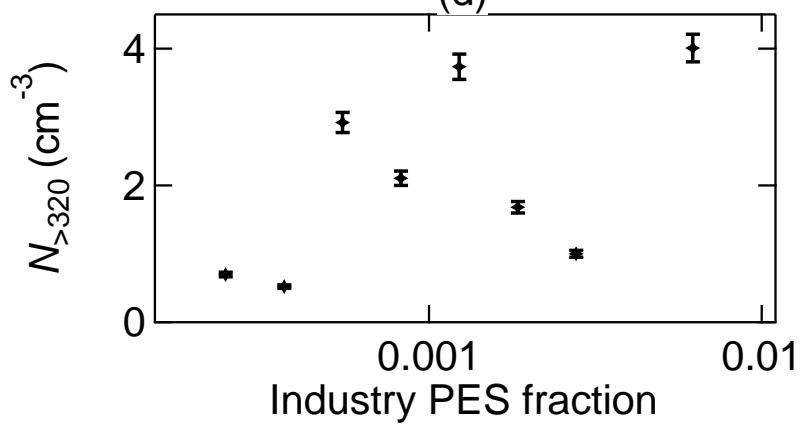

Figure S32. Averaged UHSAS number concentration in a size range between 320 and $870 \mathrm{~nm}\left(N_{>320}\right)$ as a function of FLEXPART derived PES fraction over populated areas (a-b) and industrial areas (c-d) during the Arctic (a, c) and the southern (b, d) air mass periods. Uncertainty analysis is given in Sect. 7. 


\section{S7 Uncertainty analyses}

\section{S7.1 UHSAS number concentration $\left(N_{>320}\right)$}

The absolute uncertainty of the averaged UHSAS number concentration for each bin $\left(\sigma_{N_{>320}}^{\text {abs }}\right)$ is calculated based on Poisson statistics and Gaussian propagation of uncertainties:

$\sigma_{N_{>320}}^{\mathrm{abs}}=N_{>320} \sqrt{\left(\sigma_{\mathrm{UHSAS}}^{\mathrm{rel}}\right)^{2}+\left(\sigma_{\mathrm{UHSAS}}^{\mathrm{rel}_{1}}\right)^{2}}$,

with the $\sigma_{\mathrm{UHSAS}}^{\text {rel }}$ that is defined as follows:

$\sigma_{\mathrm{UHSAS}}^{\mathrm{rel}}=\frac{1}{\sqrt{C_{>320}}}$

with the counts of particles greater than $320 \mathrm{~nm}$ in diameter $\left(C_{>320}\right)$. The $\sigma_{\text {UHSAS }}^{\mathrm{rel}_{1}}$ is $5 \%$ derived from the UHSAS collection efficiency of $95 \%$ (see Table S3).

\section{S7.2 ALABAMA particle fraction $(P F)$}

The absolute uncertainty of the ALABAMA particle fraction for each bin $\left(\sigma_{P F}^{\text {abs }}\right)$ is calculated using binomial statistics:

$\sigma_{P F}^{\mathrm{abs}}=\frac{\sqrt{N_{\mathrm{hits}} \cdot P F \cdot(1-P F)}}{N_{\text {hits }}}$,

with the number of particles that are successfully ionized by the ablation laser and create a mass spectrum ( $\left.N_{\text {hits }}\right)$ and the $P F$.

\section{S7.3 ALABAMA scaled number concentration $\left(P F \cdot N_{>320}\right)$}

The absolute uncertainty of the ALABAMA scaled number concentration for each bin $\left(\sigma_{P F \cdot N_{>32}}^{\text {abs }}\right)$ is calculated using Gaussian propagation of uncertainties:

$\sigma_{P F \cdot N_{>320}}^{\mathrm{abs}}=\sqrt{\left(P F \cdot \sigma_{N_{>320}}^{\mathrm{abs}}\right)^{2}+\left(N_{>320} \cdot \sigma_{P F}^{\mathrm{abs}}\right)^{2}}$.

\section{S7.4 Further information on complementary data}

Table S3 presents further information on the instruments deployed in this study. 


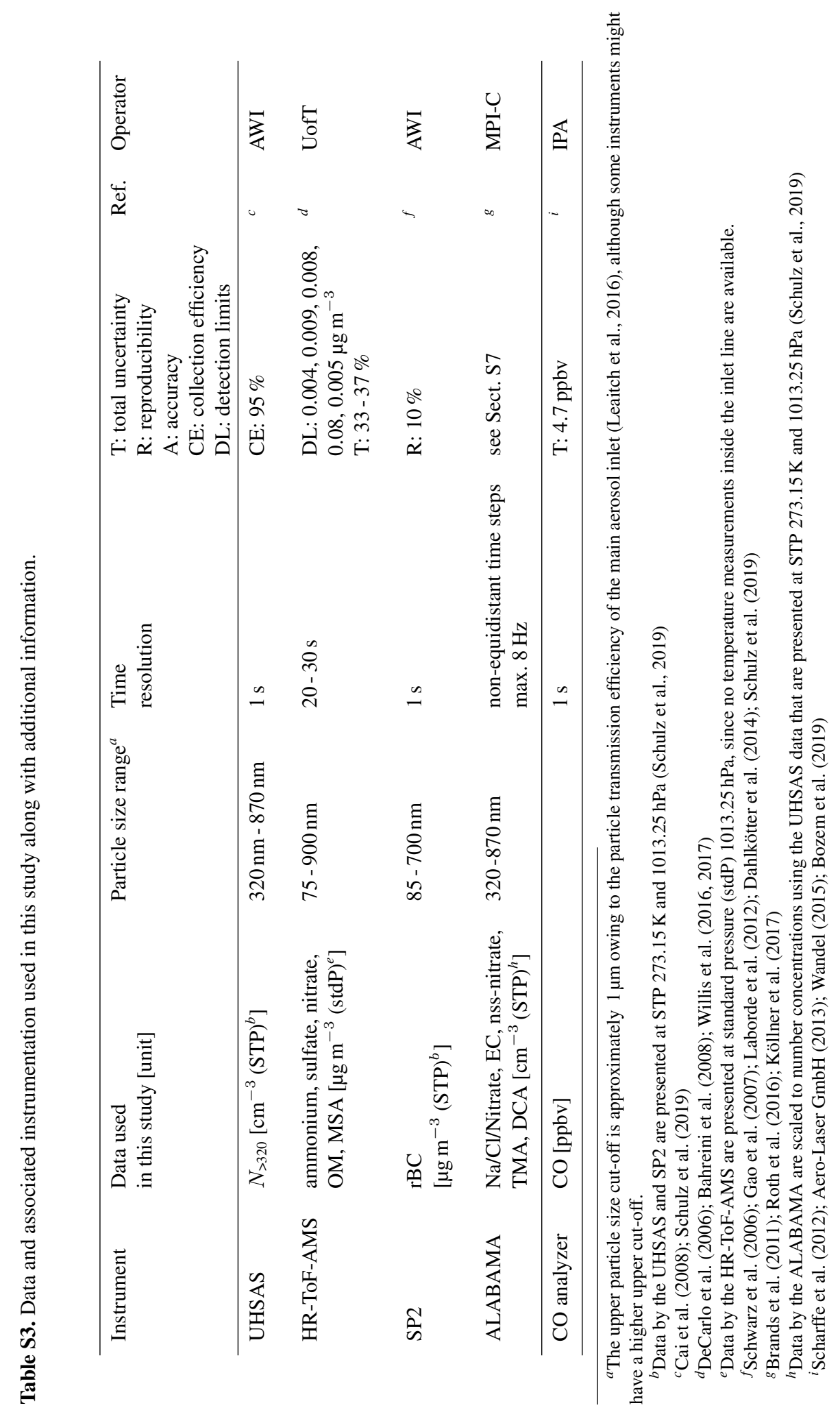


(a) Partial column $(0-400 \mathrm{~m})$

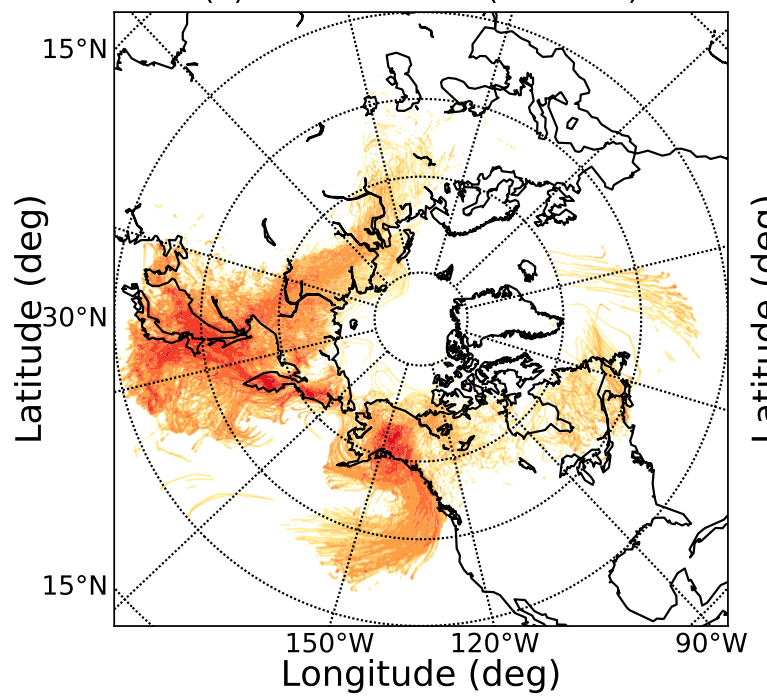

(b) Partial columns (1-15 km)

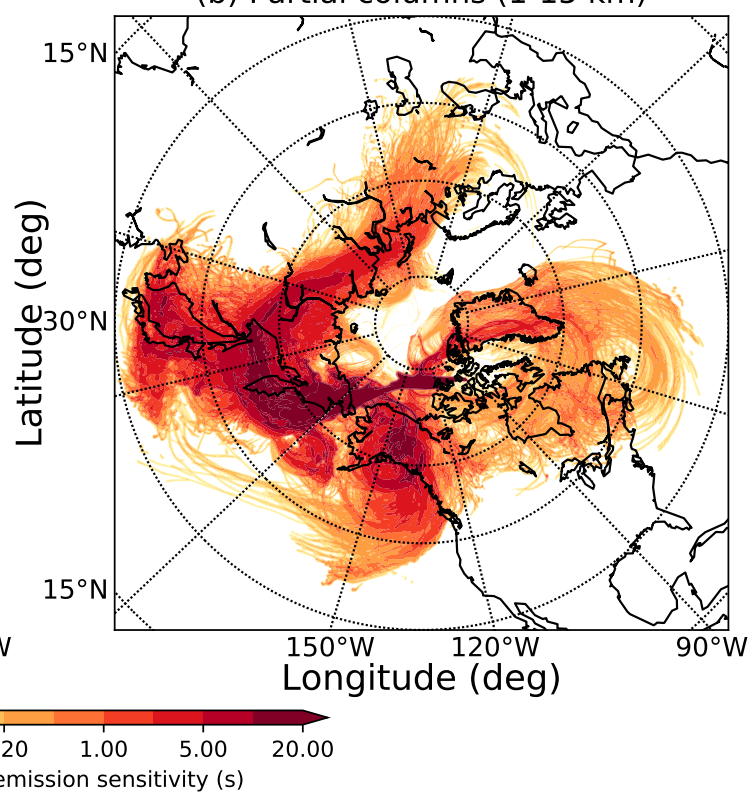

Figure S33. FLEXPART 15-days integrated (a) partial column 0 - $400 \mathrm{~m}$ and (b) partial column 1 - $15 \mathrm{~km}$ potential emission sensitivity (PES; for measurements on 5 July from 19:00 until 19:10 UTC) as an example of transport from sources in East Asia (particularly Japan) to the measurement region.

\section{S8 Examples of transport pathways}

Figures S8-S8 provide examples of transport pathways from East Asia, southern North America, Europe, and northern Canada to Arctic regions, respectively. 

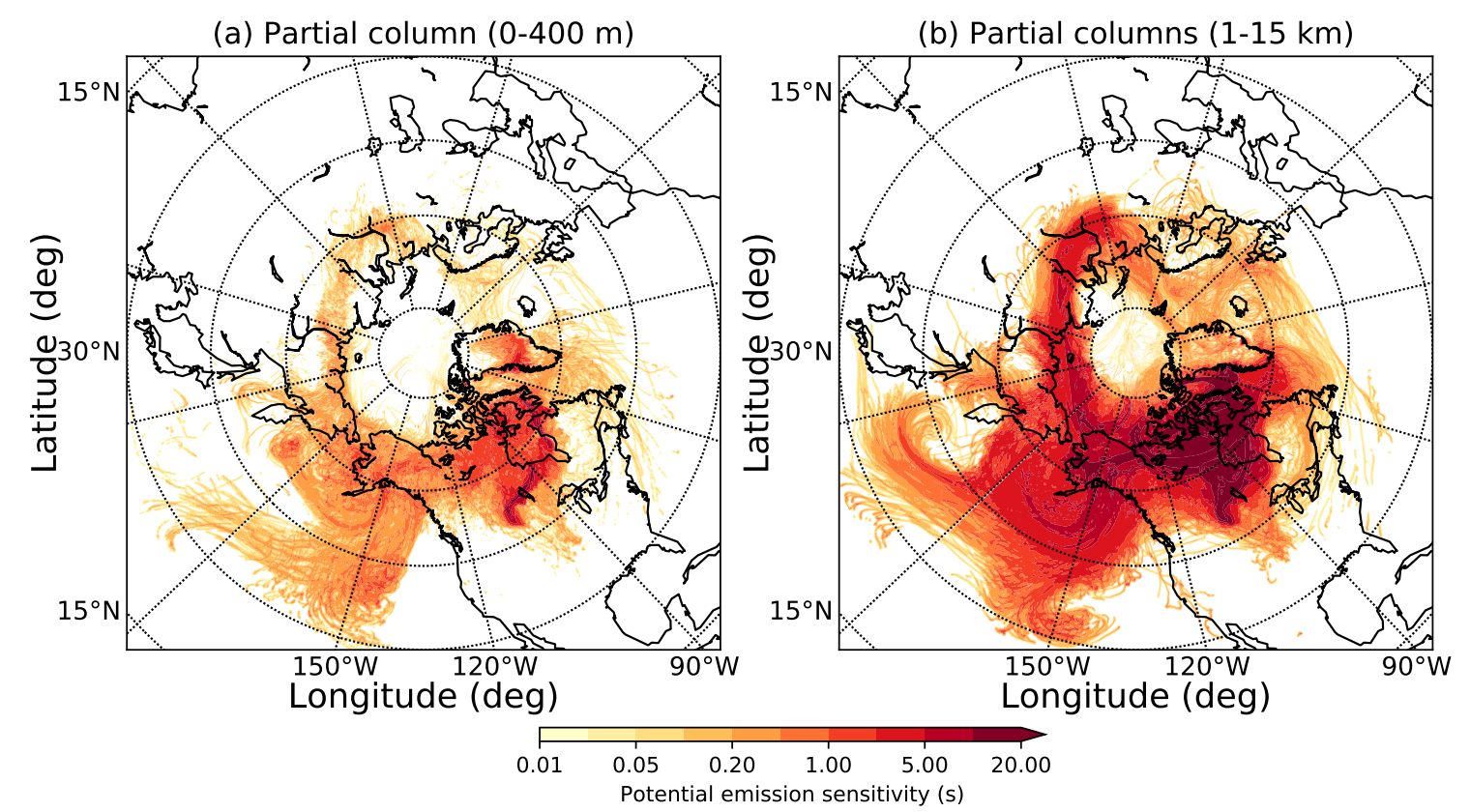

Figure S34. FLEXPART 15-days integrated (a) partial column 0 - $400 \mathrm{~m}$ and (b) partial column 1 - $15 \mathrm{~km}$ potential emission sensitivity (PES; for measurements on 21 July from 18:30 until 18:40 UTC) as an example of transport from oil field emissions in Alberta (Canada) to the measurement region. 

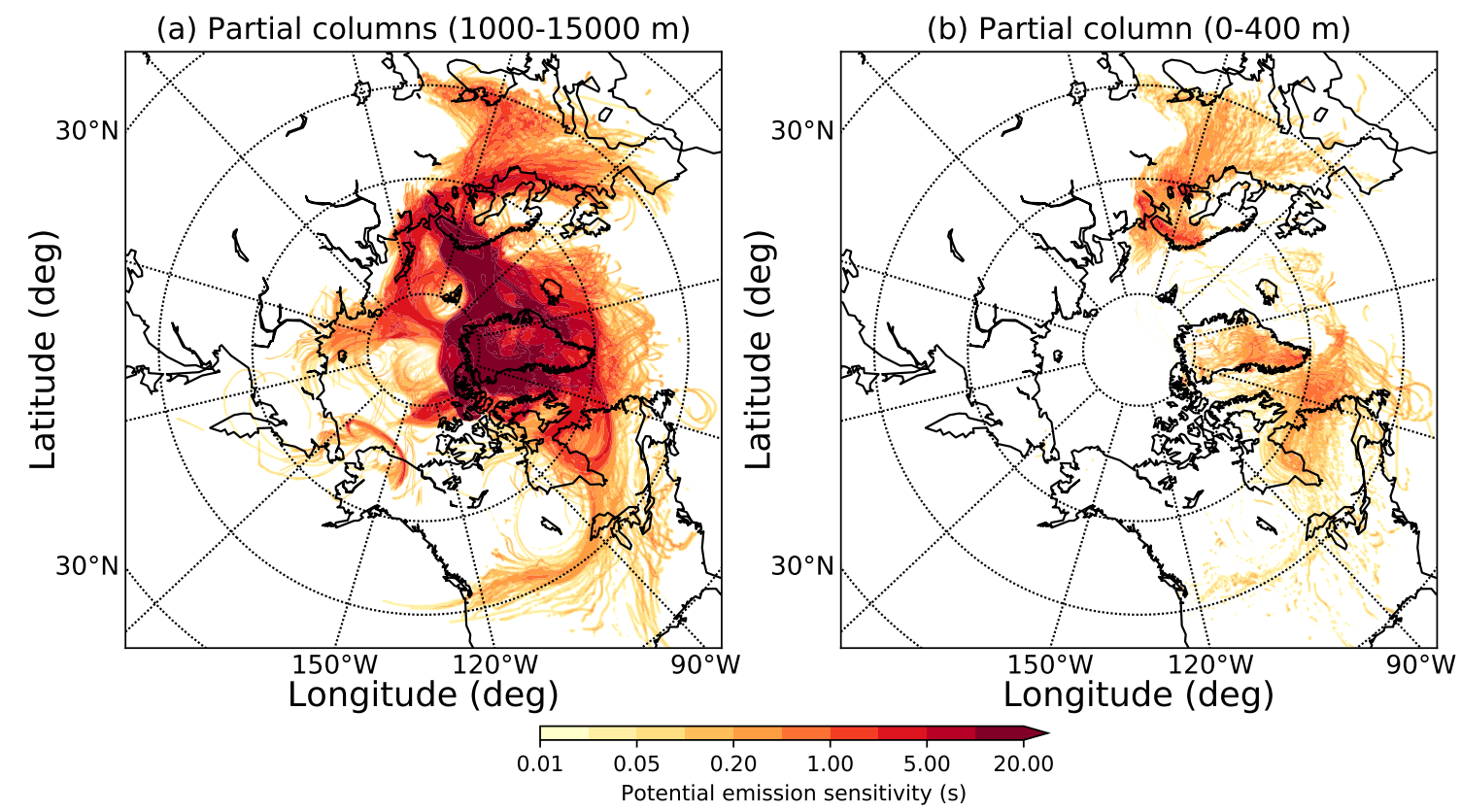

Figure S35. FLEXPART 15-days integrated (a) partial column 1 - $15 \mathrm{~km}$ and (b) partial column 0 - 400 m potential emission sensitivity (PES; for measurements on 12 July from 18:40 until 18:50 UTC) as an example of transport from European sources to the measurement region. Note that air mass transport into the Arctic took place mainly above $400 \mathrm{~m}$. 

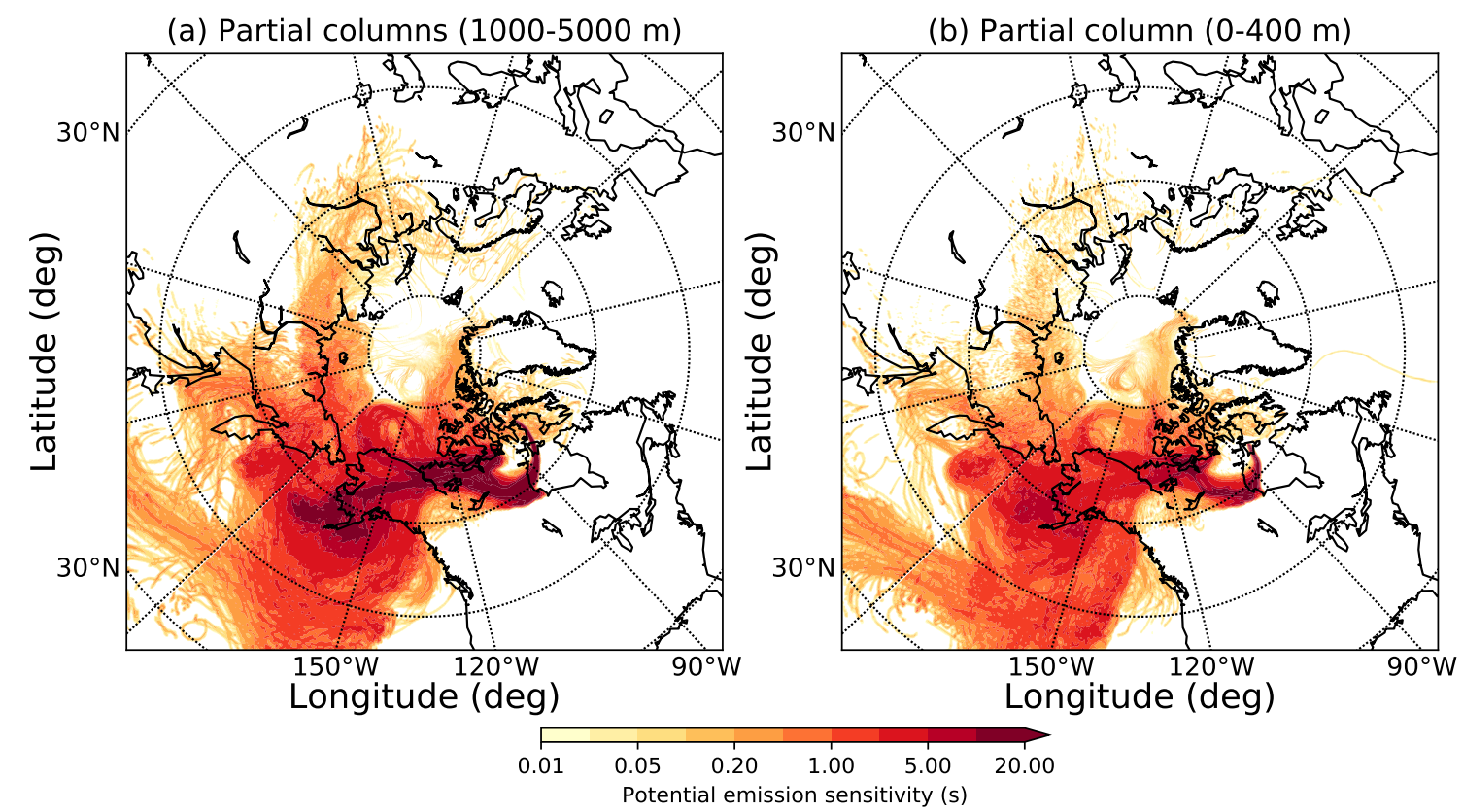

Figure S36. FLEXPART 15-days integrated (a) partial column 1 - $5 \mathrm{~km}$ and (b) partial column 0 - 400 m potential emission sensitivity (PES; for measurements on 19 July from 15:30 until 15:40 UTC) as an example of transport of emissions from vegetation fires in northern Canada (compare to Fig. 3a) to the measurement region. 


\section{S9 Pre-processing of source sector contributions}

By comparing PES fractions of different source sectors during the NETCARE 2014 measurements, two types of plumes are obvious: plumes with definite contributions from one source sector separated from other sectors (Figs. S9a-b) and plumes with mixed contributions from different source sectors (mixed plumes; Fig. S9c). However, a combination of both plume types is given in Figs. S9d-f. In such cases, mixed plumes were excluded from the further analysis, in order to provide a distinct source attribution. This had only been done if data statistics were still sufficient after selection. In detail, certain thresholds were set for selection (indicated with black boxes in Figs. S9d-f), differentiating mixed plumes from plumes of distinct source attribution. As a result for the southern air mass period, contributions from vegetation fires are separated from anthropogenic sources (Figs. S9d-e) and contributions from populated areas are separated from vegetation fires and industrial sources (Figs. S9d and f, respectively). 
(a)

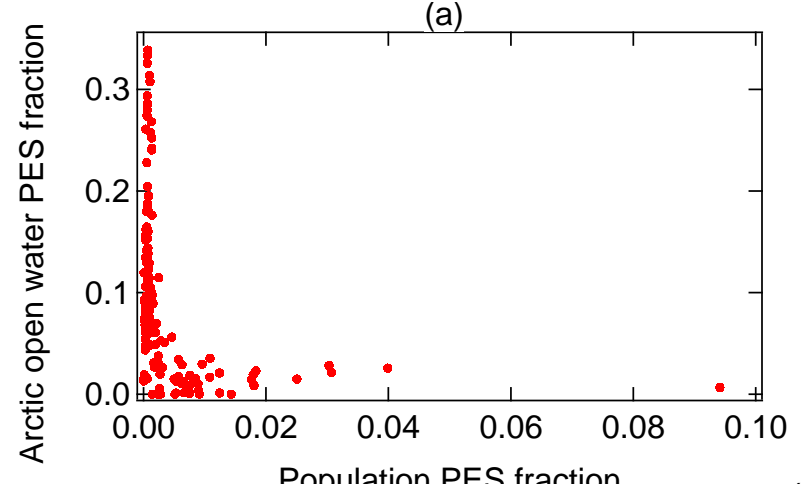

Population PES fraction

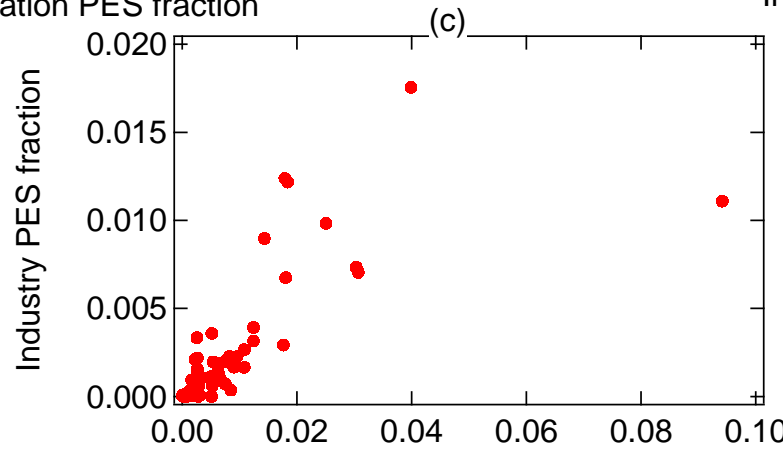

(d)

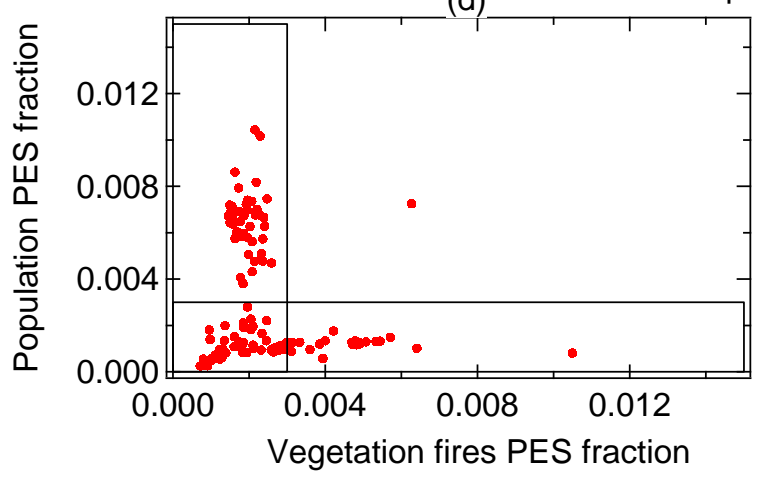

Population PES fraction

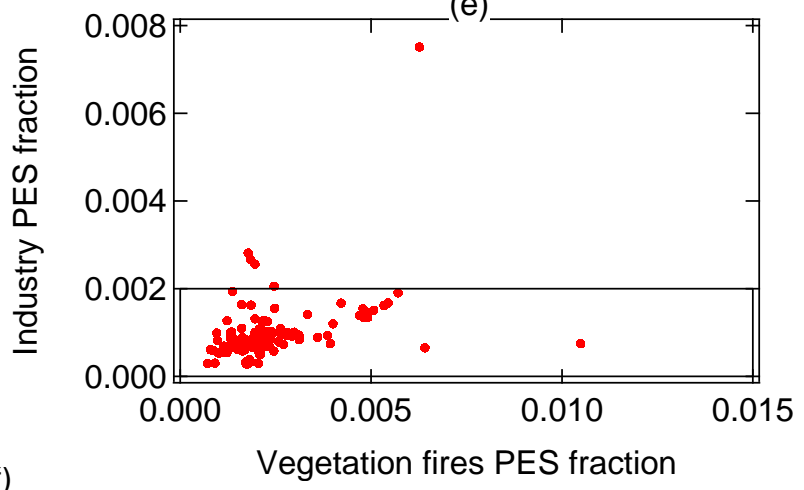

(†)

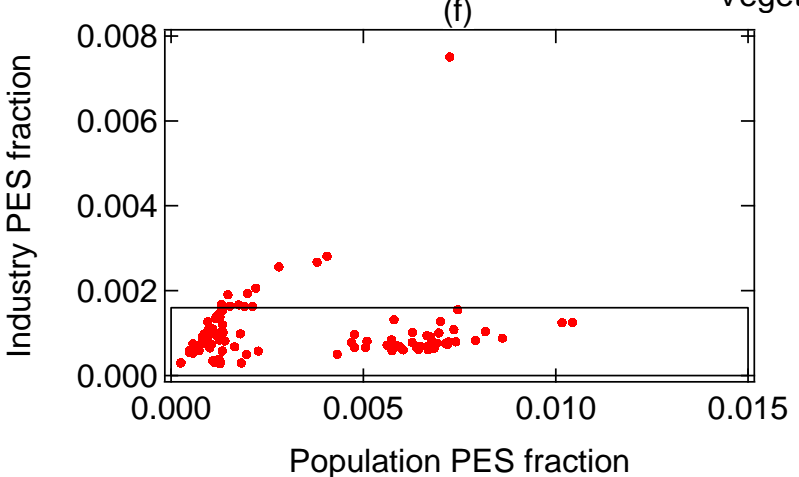

Figure S37. Comparison between different source sectors during the Arctic (a-c) and southern (d-f) air mass periods. Black boxes represent thresholds to differentiate between different sectors. 


\section{References}

Aero-Laser GmbH: Ultra-Fast Carbon-Monoxide Analyser AL5002-Manual-Version 1.24, Aero-Laser GmbH, 2013.

Andreae, M. O. and Merlet, P.: Emission of trace gases and aerosols from biomass burning, Global Biogeochem. Cy., 15, 955-966, https://doi.org/10.1029/2000GB001382, 2001.

Arndt, D. S., Blunden, J., Willett, K. W., Aaron-Morrison, A. P., Ackerman, S. A., Adamu, J. I., Albanil, A., Alfaro, E. J., Allan, R., Alley, R. B., Alvarez, L., Alves, L. M., Amador, J. A., Andreassen, L. M., Antonov, J., Applequist, S., Arendt, A., Arevalo, J., Arguez, A., Banzon, V., Barichivich, J., Baringer, M. O., Barreira, S., Baxter, S., Bazo, J., Becker, A., Behrenfeld, M. J., Bell, G. D., Benedetti, A., Bernhard, G., Berrisford, P., Berry, D. I., Bettolli, M. L., Bhatt, U. S., Bidegain, M., Bindoff, N., Bissolli, P., Blake, E. S., Blenman, R. C., Bond, N. A., Bosilovich, M., Box, J. E., Boudet, D., Boyer, T., Braathen, G. O., Bromwich, D. H., Brown, L. C., Brown, R., Bulygina, O. N., Burgess, D., Calderon, B., Camargo, S. J., Campbell, J. D., Cappelen, J., Carrasco, G., Carter, B., Chambers, D. P., Chandler, E., Chevallier, F., Christiansen, H. H., Christy, J. R., Chung, D., Ciais, P., Clem, K. R., Coelho, C. A. S., Cogley, J. G., Coldewey-Egbers, M., Colwell, S., Cooper, O. R., Copland, L., Cronin, M. F., Crouch, J., Cunningham, S. A., Davis, S. M., De Jeu, R. A. M., Degenstein, D., Demircan, M., Derksen, C., Destin, D., Diamond, H. J., Dlugokencky, J., Dohan, K., Dolman, A. J., Domingues, C. M., Donat, M. G., Dong, S., Dorigo, W. A., Drozdov, D. S., Duguay, C. R., Dunn, R. J. H., Duran-Quesada, A. M., Dutton, G. S., Ebrahim, A., Elkins, J. W., Epstein, H. E., Espinoza, J. C., Evans, T. E., Famiglietti, J. S., Fateh, S., Fauchereau, N. C., Feely, R. A., Fenimore, C., Fettweis, X., Fioletov, V. E., Flemming, J., Fogarty, C. T., Fogt, R. L., Folland, C. K., Foster, M., Francis, S. D., Franz, B. A., Freeland, H., Frith, S. M., Froidevaux, L., Frost, G. V., Ganter, C., Garzoli, S., Gerland, S., Gitau, W., Gobron, N., Goldenberg, S. B., Goni, G., Gonzalez, I. T., Good, S. A., Goto, A., Griffin, K. S., Grist, J., Grooss, J. U., Guard, C., Gupta, S. K., Hagos, S., Haimberger, L., Hall, B. D., Halpert, M. S., Hamlington, B. D., Hanna, E., Hanssen-Bauer, I., Harris, I., Heidinger, A. K., Heikkila, A., Heim, R. R., Hendricks, S., Hernandez, M., Hidalgo, H. G., Hilburn, K., Ho, S. P., Hobbs, W. R., Hu, Z. Z., Huelsing, H., Hurst, D. F., Inness, A., Ishii, M., Jeffers, B., Jeffries, M. O., Jevrejeva, S., Jin, X. Z., John, V., Johns, W. E., Johnsen, B., Johnson, B., Johnson, G. C., Jones, P. D., Josey, S. A., Joyette, S., Jumaux, G., Kabidi, K., Kaiser, J. W., Kang, K. K., Kanzow, T. O., Kao, H. Y., Kazemi, A., Keller, L. M., Kendon, M., Kennedy, J., Kerr, K., Kheyrollah Pour, H., Kholodov, A. L., Khoshkam, M., Kidd, R., Kieke, D., Kim, H., Kim, S. J., Kimberlain, T. B., Klotzbach, P., Knaff, J. A., Kobayashi, S., Kohler, J., Korshunova, N. N., Koskela, T., Kramarova, N., Kratz, D. P., Kruger, A., Kruk, M. C., Kumar, A., Kwok, R., Lagerloef, G. S. E., Lakkala, K., Lander, M. A., Landsea, C. W., Lankhorst, M., Lantz, K., Lazzara, M. A., Leuliette, E., L'Heureux, M., Lieser, J. L., Lin, I. I., Liu, H., Liu, Y., Locarnini, R., Loeb, N. G., Long, C. S., Lorrey, A. M., Loyola, D., Lui, Y. Y., Lumpkin, R., Luo, J. J., Luojus, K., Lyman, J. M., Macara, G. R., Maddux, B. C., Malkova, G. V., Manney, G., Marcellin-Honore, V., Marchenko, S. S., Marengo, J. A., Marra, J. J., Martinez-Guingla, R., Massom, R. A., Mata, M. M., Mathis, J. T., Mazloff, M., McBride, C., McCarthy, G., McGree, S., McLean, N., McVicar, T. R., Mears, C. A., Meier, W., Meinen, C. S., Mekonnen, A., Melzer, T., Menendez, M., Mengistu Tsidu, G., Meredith, M. P., Merrifield, M. A., Mitchum, G. T., Monteiro, P., Montzka, S. A., Morice, C., Mote, T., Mudryk, L., Muhle, J., Mullan, A. B., Muller, R., Nash, E. R., Naveira Garabato, A. C., Nerem, R. S., Newman, L., Newman, P. A., Nicolaus, M., Nieto, J. J., Noetzli, J., O’Neel, S., Oberman, N. G., Ogallo, L. A., Oki, T., Oludhe, C. S., Osborn, T. J., Overland, J., Oyunjargal, L., Pabon, D., Parinussa, R. M., Park, E. H., Parker, D., Parsons, R., Pasch, R. J., Pascual-Ramirez, R., Pelto, M. S., Peng, L., Perovich, D., Persson, P. O. G., Peterson, T. C., Petropavlovskikh, I., Peuch, V. H., Pezza, A. B., Phillips, D., Photiadou, C., Pinty, B., Pitts, M. C., Porter, A. O., Proshutinsky, A., Quegan, S., Quintana, J., Rahimzadeh, F., Rajeevan, M., Ramos, A., Raynor, D., Razuvaev, V. N., Reagan, J., Reid, P., Reimer, C., Remy, S., Rennie, J., Renwick, J. A., Revadekar, J. V., Richter-Menge, J. A., Robinson, D. A., Rodell, M., Romanovsky, V. E., Ronchail, J., Rosenlof, K. H., Roth, C., Sabine, C. L., Sallee, J. B., Sanchez-Lugo, A., Santee, M. L., Sawaengphokhai, P., Sayouri, A., Scambos, T. A., Schemm, J., Schmid, C., Schmidtko, S., Schreck, C. J., Send, U., Sensoy, S., Setzer, A., Sharp, M., Shaw, A., Shi, L., Shiklomanov, N. I., Shu, S., Shupe, M. D., Siegel, D. A., Sima, F., Simmons, A. J., Smeed, D. A., Smeets, C., Smith, C., Smith, S. L., Smith, T. M., Spence, J. M., Srivastava, A. K., Stackhouse Jr, P. W., Stammerjohn, S., Steinbrecht, W., Stella, J. L., Stephenson, K., Stephenson, T. S., Strahan, S., Strel: Bulletin of the American Meteorological Society, chap. State of the Climate in 2014, State of the Climate, https://repository.library.noaa.gov/view/noaa/17469, journal Article, 2015.

Bahreini, R., Dunlea, E. J., Matthew, B. M., Simons, C., Docherty, K. S., DeCarlo, P. F., Jimenez, J. L., Brock, C. A., and Middlebrook, A. M.: Design and Operation of a Pressure-Controlled Inlet for Airborne Sampling with an Aerodynamic Aerosol Lens, Aerosol Sci. Technol., 42, 465-471, https://doi.org/10.1080/02786820802178514, 2008.

Bozem, H., Hoor, P., Kunkel, D., Köllner, F., Schneider, J., Herber, A., Schulz, H., Leaitch, W. R., Aliabadi, A. A., Willis, M. D., Burkart, J., and Abbatt, J. P. D.: Characterization of Transport Regimes and the Polar Dome during Arctic Spring and Summer using in-situ Aircraft Measurements, Atmos. Chem. Phys. Discuss., 2019, 1-36, https://doi.org/10.5194/acp-2019-70, 2019.

Brands, M., Kamphus, M., Böttger, T., Schneider, J., Drewnick, F., Roth, A., Curtius, J., Voigt, C., Borbon, A., Beekmann, M., Bourdon, A., Perrin, T., and Borrmann, S.: Characterization of a Newly Developed Aircraft-Based Laser Ablation Aerosol Mass Spectrometer (ALABAMA) and First Field Deployment in Urban Pollution Plumes over Paris During MEGAPOLI 2009, Aerosol Sci. Technol., 45, 46-64, https://doi.org/10.1080/02786826.2010.517813, 2011. 
Cai, Y., Montague, D. C., Mooiweer-Bryan, W., and Deshler, T.: Performance characteristics of the ultra high sensitivity aerosol spectrometer for particles between 55 and $800 \mathrm{~nm}$ : Laboratory and field studies, J. Aerosol Sci., 39, 759 - 769, https://doi.org/10.1016/j.jaerosci.2008. 04.007, 2008.

Cavalieri, D. J., Parkinson, C. L., Gloersen, P., and Zwally, H. J.: Sea Ice Concentrations from Nimbus-7 SMMR and DMSP SSM/I-SSMIS Passive Microwave Data, Version 1, NSIDC-0051, Boulder, Colorado USA. NASA National Snow and Ice Data Center Distributed Active Archive Center, https://doi.org/https://doi.org/10.5067/8GQ8LZQVL0VL, last access: 08.06.2018, 1996, updated yearly.

Clemen, H.-C., Schneider, J., Klimach, T., Helleis, F., Köllner, F., Hünig, A., Rubach, F., Mertes, S., Wex, H., Stratmann, F., Welti, A., Kohl, R., Frank, F., and Borrmann, S.: Optimizing the detection, ablation, and ion extraction efficiency of a single-particle laser ablation mass spectrometer for application in environments with low aerosol particle concentrations, Atmospheric Measurement Techniques, 13, 5923-5953, https://doi.org/10.5194/amt-13-5923-2020, https://amt.copernicus.org/articles/13/5923/2020/, 2020.

Corbin, J., Rehbein, P., Evans, G., and Abbatt, J.: Combustion particles as ice nuclei in an urban environment: Evidence from single-particle mass spectrometry., Atmos. Environ., 51, 286-292, https://doi.org/10.1016/j.atmosenv.2012.01.007, 2012.

Dahlkötter, F., Gysel, M., Sauer, D., Minikin, A., Baumann, R., Seifert, P., Ansmann, A., Fromm, M., Voigt, C., and Weinzierl, B.: The Pagami Creek smoke plume after long-range transport to the upper troposphere over Europe - aerosol properties and black carbon mixing state, Atmos. Chem. Phys., 14, 6111-6137, https://doi.org/10.5194/acp-14-6111-2014, 2014.

DeCarlo, P. F., Kimmel, J. R., Trimborn, A., Northway, M. J., Jayne, J. T., Aiken, A. C., Gonin, M., Fuhrer, K., Horvath, T., Docherty, K. S., Worsnop, D. R., and Jimenez, J. L.: Field-Deployable, High-Resolution, Time-of-Flight Aerosol Mass Spectrometer, Anal. Chem., 78, 8281-8289, https://doi.org/10.1021/ac061249n, 2006.

Elvidge, C. D., Zhizhin, M., Hsu, F.-C., and Baugh, K. E.: VIIRS Nightfire: Satellite Pyrometry at Night, Remote Sensing, 5, 4423-4449, https://doi.org/10.3390/rs5094423, 2013.

Elvidge, C. D., Zhizhin, M., Baugh, K., Hsu, F.-C., and Ghosh, T.: Methods for Global Survey of Natural Gas Flaring from Visible Infrared Imaging Radiometer Suite Data, Energies, 9, https://doi.org/10.3390/en9010014, 2016.

Fuelberg, H. E., Harrigan, D. L., and Sessions, W.: A meteorological overview of the ARCTAS 2008 mission, Atmos. Chem. Phys., 10, 817-842, https://doi.org/10.5194/acp-10-817-2010, 2010.

Gao, R. S., Schwarz, J. P., Kelly, K. K., Fahey, D. W., Watts, L. A., Thompson, T. L., Spackman, J. R., Slowik, J. G., Cross, E. S., Han, J.-H., Davidovits, P., Onasch, T. B., and Worsnop, D. R.: A Novel Method for Estimating Light-Scattering Properties of Soot Aerosols Using a Modified Single-Particle Soot Photometer, Aerosol Sci. Technol., 41, 125-135, https://doi.org/10.1080/02786820601118398, 2007.

Giglio, L., Randerson, J. T., and van der Werf, G. R.: Analysis of daily, monthly, and annual burned area using the fourth-generation global fire emissions database (GFED4), J. Geophys. Res.-Biogeo., 118, 317-328, https://doi.org/10.1002/jgrg.20042, 2013.

Guasco, T. L., Cuadra-Rodriguez, L. A., Pedler, B. E., Ault, A. P., Collins, D. B., Zhao, D., Kim, M. J., Ruppel, M. J., Wilson, S. C., Pomeroy, R. S., Grassian, V. H., Azam, F., Bertram, T. H., and Prather, K. A.: Transition Metal Associations with Primary Biological Particles in Sea Spray Aerosol Generated in a Wave Channel, Environ. Sci. Technol., 48, 1324-1333, https://doi.org/10.1021/es403203d, 2014.

Kalnay, E., Kanamitsu, M., Kistler, R., Collins, W., Deaven, D., Gandin, L., Iredell, M., Saha, S., White, G., Woollen, J., Zhu, Y., Chelliah, M., Ebisuzaki, W., Higgins, W., Janowiak, J., Mo, K. C., Ropelewski, C., Wang, J., Leetmaa, A., Reynolds, R., Jenne, R., and Joseph, D.: The NCEP/NCAR 40-Year Reanalysis Project, B. Am. Meteorol. Soc., 77, 437-472, https://doi.org/10.1175/15200477(1996)077<0437:TNYRP>2.0.CO;2, 1996.

Köllner, F., Schneider, J., Willis, M. D., Klimach, T., Helleis, F., Bozem, H., Kunkel, D., Hoor, P., Burkart, J., Leaitch, W. R., Aliabadi, A. A., Abbatt, J. P. D., Herber, A. B., and Borrmann, S.: Particulate trimethylamine in the summertime Canadian high Arctic lower troposphere, Atmos. Chem. Phys., 17, 13 747-13 766, https://doi.org/10.5194/acp-17-13747-2017, 2017.

Kondo, Y., Matsui, H., Moteki, N., Sahu, L., Takegawa, N., Kajino, M., Zhao, Y., Cubison, M. J., Jimenez, J. L., Vay, S., Diskin, G. S., Anderson, B., Wisthaler, A., Mikoviny, T., Fuelberg, H. E., Blake, D. R., Huey, G., Weinheimer, A. J., Knapp, D. J., and Brune, W. H.: Emissions of black carbon, organic, and inorganic aerosols from biomass burning in North America and Asia in 2008, J. Geophys. Res.Atmos., 116, https://doi.org/10.1029/2010JD015152, 2011.

Laborde, M., Mertes, P., Zieger, P., Dommen, J., Baltensperger, U., and Gysel, M.: Sensitivity of the Single Particle Soot Photometer to different black carbon types, Atmos. Meas. Tech., 5, 1031-1043, https://doi.org/10.5194/amt-5-1031-2012, 2012.

Lavoué, D., Liousse, C., Cachier, H., Stocks, B. J., and Goldammer, J. G.: Modeling of carbonaceous particles emitted by boreal and temperate wildfires at northern latitudes, J. Geophys. Res.-Atmos, 105, 26 871-26 890, https://doi.org/10.1029/2000JD900180, 2000.

Leaitch, W. R., Korolev, A., Aliabadi, A. A., Burkart, J., Willis, M. D., Abbatt, J. P. D., Bozem, H., Hoor, P., Köllner, F., Schneider, J., Herber, A., Konrad, C., and Brauner, R.: Effects of 20-100 nm particles on liquid clouds in the clean summertime Arctic, Atmos. Chem. Phys., 16, 11 107-11 124, https://doi.org/10.5194/acp-16-11107-2016, 2016.

Lee, S.-H., Murphy, D. M., Thomson, D. S., and Middlebrook, A. M.: Nitrate and oxidized organic ions in single particle mass spectra during the 1999 Atlanta Supersite Project, J. Geophys. Res.-Atmos, 108, https://doi.org/10.1029/2001JD001455, 8471, 2003. 
Leung, F.-Y. T., Logan, J. A., Park, R., Hyer, E., Kasischke, E., Streets, D., and Yurganov, L.: Impacts of enhanced biomass burning in the boreal forests in 1998 on tropospheric chemistry and the sensitivity of model results to the injection height of emissions, J. Geophys. Res.-Atmos, 112, https://doi.org/10.1029/2006JD008132, 2007.

Liu, Y., Hu, C., Zhan, W., Sun, C., Murch, B., and Ma, L.: Identifying industrial heat sources using time-series of the VIIRS Nightfire product with an object-oriented approach, Remote Sens. Environ., 204, 347 - 365, https://doi.org/10.1016/j.rse.2017.10.019, 2018.

MaxMind: https://www.maxmind.com/en/free-world-cities-database, last access: 10.06.2018, 2018.

Moffet, R. C., de Foy, B., Molina, L. T., Molina, M. J., and Prather, K. A.: Measurement of ambient aerosols in northern Mexico City by single particle mass spectrometry, Atmos. Chem. Phys., 8, 4499-4516, https://doi.org/10.5194/acp-8-4499-2008, 2008.

NASA: https://doi.org/10.5067/FIRMS/VIIRS/VNP14IMGT.NRT.001., https://firms.modaps.eosdis.nasa.gov, last access: 29.09.2018, 2018.

NOAA: https://www.ngdc.noaa.gov/eog/viirs/download_viirs_fire.html, last access: 01.10.2018, 2018a.

NOAA: https://data.ngdc.noaa.gov/instruments/remote-sensing/passive/spectrometers-radiometers/imaging/viirs/vnf/v21/flares/, last access: February 2018, 2018b.

Prather, K. A., Bertram, T. H., Grassian, V. H., Deane, G. B., Stokes, M. D., DeMott, P. J., Aluwihare, L. I., Palenik, B. P., Azam, F., Seinfeld, J. H., Moffet, R. C., Molina, M. J., Cappa, C. D., Geiger, F. M., Roberts, G. C., Russell, L. M., Ault, A. P., Baltrusaitis, J., Collins, D. B., Corrigan, C. E., Cuadra-Rodriguez, L. A., Ebben, C. J., Forestieri, S. D., Guasco, T. L., Hersey, S. P., Kim, M. J., Lambert, W. F., Modini, R. L., Mui, W., Pedler, B. E., Ruppel, M. J., Ryder, O. S., Schoepp, N. G., Sullivan, R. C., and Zhao, D.: Bringing the ocean into the laboratory to probe the chemical complexity of sea spray aerosol, P. Natl. Acad. Sci., 110, 7550-7555, https://doi.org/10.1073/pnas.1300262110, 2013.

Pratt, K. A., DeMott, P. J., French, J. R., Wang, Z., Westphal, D. L., Heymsfield, A. J., Twohy, C. H., Prenni, A. J., and Prather, K. A.: In situ detection of biological particles in cloud ice-crystals, Nature Geoscience, 2, 398-401, https://doi.org/10.1038/ngeo521, 2009.

Roth, A., Schneider, J., Klimach, T., Mertes, S., van Pinxteren, D., Herrmann, H., and Borrmann, S.: Aerosol properties, source identification, and cloud processing in orographic clouds measured by single particle mass spectrometry on a central European mountain site during HCCT-2010, Atmos. Chem. Phys., 16, 505-524, https://doi.org/10.5194/acp-16-505-2016, 2016.

Scharffe, D., Slemr, F., Brenninkmeijer, C. A. M., and Zahn, A.: Carbon monoxide measurements onboard the CARIBIC passenger aircraft using UV resonance fluorescence, Atmos. Meas. Tech., 5, 1753-1760, https://doi.org/10.5194/amt-5-1753-2012, 2012.

Schmidt, S.: Analyse der chemischen Zusammensetzung von Eis- und Wolkenresiduen mittels Einzelpartikel-Massenspektrometrie und Charakterisierung von Aerosolpartikeln aus anthropogenen und natürlichen Quellen, Ph.D. thesis, Johannes Gutenberg-Universität Mainz, 2015.

Schmidt, S., Schneider, J., Klimach, T., Mertes, S., Schenk, L. P., Kupiszewski, P., Curtius, J., and Borrmann, S.: Online single particle analysis of ice particle residuals from mountain-top mixed-phase clouds using laboratory derived particle type assignment, Atmos. Chem. Phys., 17, 575-594, https://doi.org/10.5194/acp-17-575-2017, 2017.

Schroeder, W. and Giglio, L.: NASA VIIRS Land Science Investigator Processing System (SIPS) Visible Infrared Imaging Radiometer Suite (VIIRS) 375 m \& 750 m Active Fire Products: Product User's Guide Version 1.4, Tech. rep., Department of Geographical Sciences, University of Maryland, 2018.

Schroeder, W., Oliva, P., Giglio, L., and Csiszar, I. A.: The New VIIRS 375m active fire detection data product: Algorithm description and initial assessment, Remote Sens. Environ., 143, 85 - 96, https://doi.org/10.1016/j.rse.2013.12.008, 2014.

Schulz, H., Zanatta, M., Bozem, H., Leaitch, W. R., Herber, A. B., Burkart, J., Willis, M. D., Kunkel, D., Hoor, P. M., Abbatt, J. P. D., and Gerdes, R.: High Arctic aircraft measurements characterising black carbon vertical variability in spring and summer, Atmos. Chem. Phys., 2019, 2361-2384, https://doi.org/10.5194/acp-19-2361-2019, 2019.

Schwarz, J. P., Gao, R. S., Fahey, D. W., Thomson, D. S., Watts, L. A., Wilson, J. C., Reeves, J. M., Darbeheshti, M., Baumgardner, D. G., Kok, G. L., Chung, S. H., Schulz, M., Hendricks, J., Lauer, A., Kärcher, B., Slowik, J. G., Rosenlof, K. H., Thompson, T. L., Langford, A. O., Loewenstein, M., and Aikin, K. C.: Single-particle measurements of midlatitude black carbon and light-scattering aerosols from the boundary layer to the lower stratosphere, J. Geophys. Res.-Atmos., 111, https://doi.org/10.1029/2006JD007076, 2006.

Silva, P. J. and Prather, K. A.: Interpretation of Mass Spectra from Organic Compounds in Aerosol Time-of-Flight Mass Spectrometry, Anal. Chem., 72, 3553-3562, https://doi.org/10.1021/ac9910132, 2000.

Silva, P. J., Liu, D.-Y., Noble, C. A., and Prather, K. A.: Size and Chemical Characterization of Individual Particles Resulting from Biomass Burning of Local Southern California Species, Environ. Sci. Technol., 33, 3068-3076, https://doi.org/10.1021/es980544p, 1999.

Simoneit, B., Schauer, J., Nolte, C., Oros, D., Elias, V., Fraser, M., Rogge, W., and Cass, G.: Levoglucosan, a tracer for cellulose in biomass burning and atmospheric particles, Atmos. Environ., 33, 173-182, https://doi.org/10.1016/S1352-2310(98)00145-9, 1999.

Snyder, J. P.: Map projections used by the U.S. Geological Survey, Tech. rep., Washington, D.C., http://pubs.er.usgs.gov/publication/b1532, report, 1982.

Stohl, A.: Characteristics of atmospheric transport into the Arctic troposphere, J. Geophys. Res.-Atmos., 111, https://doi.org/10.1029/2005JD006888, 2006. 
Tjernström, M., Birch, C. E., Brooks, I. M., Shupe, M. D., Persson, P. O. G., Sedlar, J., Mauritsen, T., Leck, C., Paatero, J., Szczodrak, M., and Wheeler, C. R.: Meteorological conditions in the central Arctic summer during the Arctic Summer Cloud Ocean Study (ASCOS), Atmos. Chem. Phys., 12, 6863-6889, https://doi.org/10.5194/acp-12-6863-2012, 2012.

Trimborn, A., Hinz, K.-P., and Spengler, B.: Online analysis of atmospheric particles with a transportable laser mass spectrometer during LACE 98, J. Geophys. Res.-Atmos., 107, https://doi.org/10.1029/2001JD000590, 2002.

Turquety, S., Logan, J. A., Jacob, D. J., Hudman, R. C., Leung, F. Y., Heald, C. L., Yantosca, R. M., Wu, S., Emmons, L. K., Edwards, D. P., and Sachse, G. W.: Inventory of boreal fire emissions for North America in 2004: Importance of peat burning and pyroconvective injection, J. Geophys. Res.-Atmos., 112, https://doi.org/10.1029/2006JD007281, 2007.

Val Martin, M., Kahn, R. A., and Tosca, M. G.: A Global Analysis of Wildfire Smoke Injection Heights Derived from Space-Based MultiAngle Imaging, Remote Sensing, 10, https://doi.org/10.3390/rs10101609, 2018.

Wandel, M.: CO-Messung in der Arktis im Rahmen der NETCARE-Kampa-gne, Master's thesis, Johannes Gutenberg-Universität Mainz, 2015 .

Willis, M. D., Burkart, J., Thomas, J. L., Köllner, F., Schneider, J., Bozem, H., Hoor, P. M., Aliabadi, A. A., Schulz, H., Herber, A. B., Leaitch, W. R., and Abbatt, J. P. D.: Growth of nucleation mode particles in the summertime Arctic: a case study, Atmos. Chem. Phys., 16, 7663-7679, https://doi.org/10.5194/acp-16-7663-2016, 2016.

Willis, M. D., Köllner, F., Burkart, J., Bozem, H., Thomas, J. L., Schneider, J., Aliabadi, A. A., Hoor, P. M., Schulz, H., Herber, A. B., Leaitch, W. R., and Abbatt, J. P. D.: Evidence for marine biogenic influence on summertime Arctic aerosol, Geophys. Res. Lett., 44, 6460-6470, https://doi.org/10.1002/2017GL073359, 2017.

Zauscher, M. D., Wang, Y., Moore, M. J. K., Gaston, C. J., and Prather, K. A.: Air Quality Impact and Physicochemical Aging of Biomass Burning Aerosols during the 2007 San Diego Wildfires, Environ. Sci. Technol., 47, 7633-7643, https://doi.org/10.1021/es4004137, 2013. 